Prepared in Cooperation with the Crawford County Conservation District and Fairfield Township, Pennsylvania

\title{
Simulations of Flow and Prediction of Sediment Movement in Wymans Run, Cochranton Borough, Crawford County, Pennsylvania
}

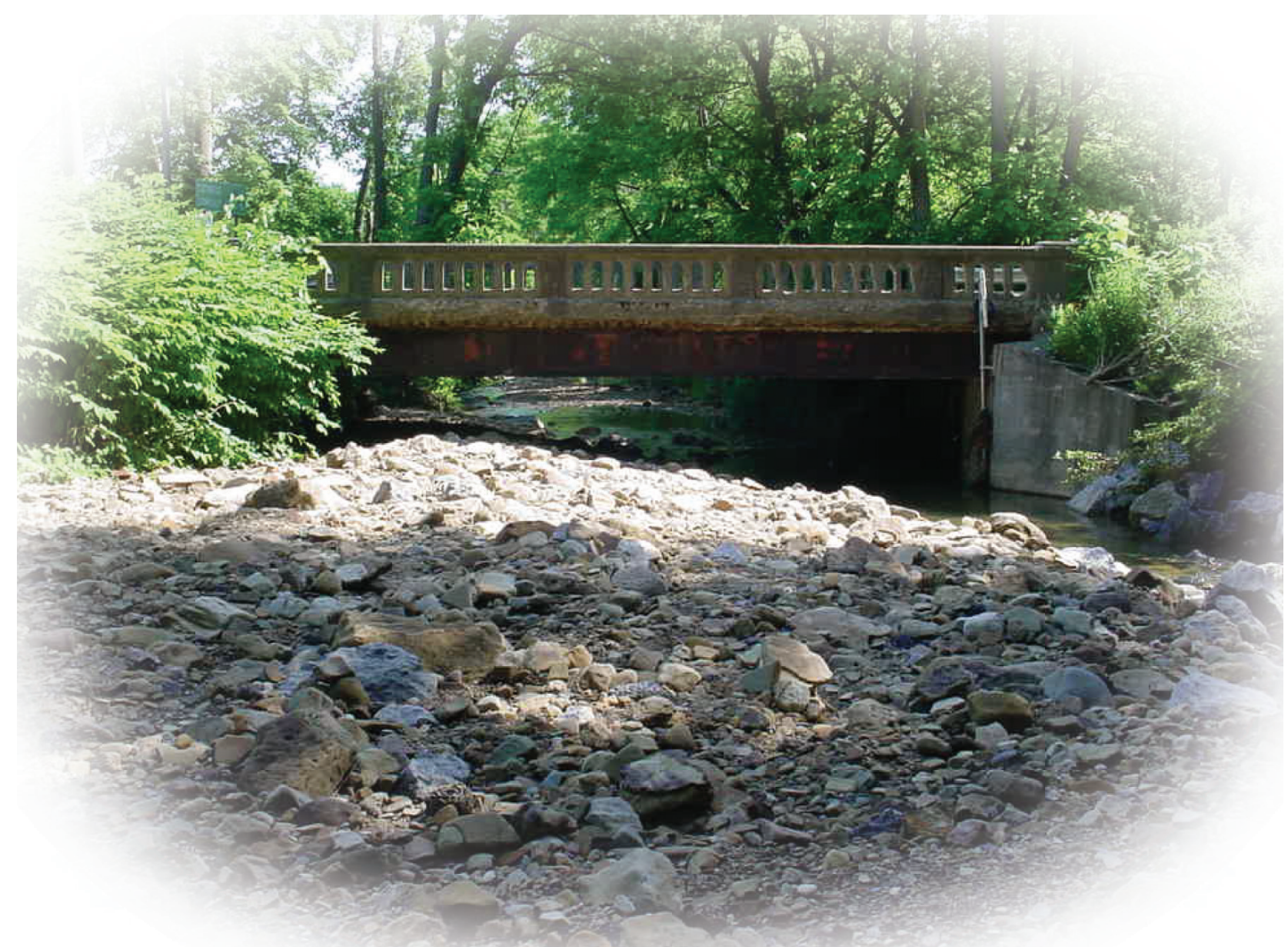

Open-File Report 2011-1223

U.S. Department of the Interior

U.S. Geological Survey 
Cover. Photo of upstream opening of PA 28 bridge after the June 5, 2008 storm (Photograph by Elizabeth Hittle, U.S. Geological Survey, June 25, 2008) 


\section{Simulations of Flow and Prediction of Sediment Movement in Wymans Run, Cochranton Borough, Crawford County, Pennsylvania}

By Elizabeth Hittle

Prepared in Cooperation with the

Crawford County Conservation District and Fairfield Township, Pennsylvania

Open-File Report 2011-1223 


\title{
U.S. Department of the Interior \\ KEN SALAZAR, Secretary \\ U.S. Geological Survey \\ Marcia K. McNutt, Director
}

\author{
U.S. Geological Survey, Reston, Virginia: 2011
}

For more information on the USGS - the Federal source for science about the Earth, its natural and living resources, natural hazards, and the environment, visit http://www.usgs.gov or call 1-888-ASK-USGS.

For an overview of USGS information products, including maps, imagery, and publications, visit http://www.usgs.gov/pubprod

To order this and other USGS information products, visit http://store.usgs.gov

Any use of trade, product, or firm names is for descriptive purposes only and does not imply endorsement by the U.S. Government.

Although this report is in the public domain, permission must be secured from the individual copyright owners to reproduce any copyrighted materials contained within this report.

Suggested citation:

Hittle, Elizabeth, 2011, Simulations of flow and prediction of sediment movement in Wymans Run, Cochranton Borough, Crawford County, Pennsylvania: U.S. Geological Survey Open-File Report 2011-1223, 25 p. 


\section{Contents}

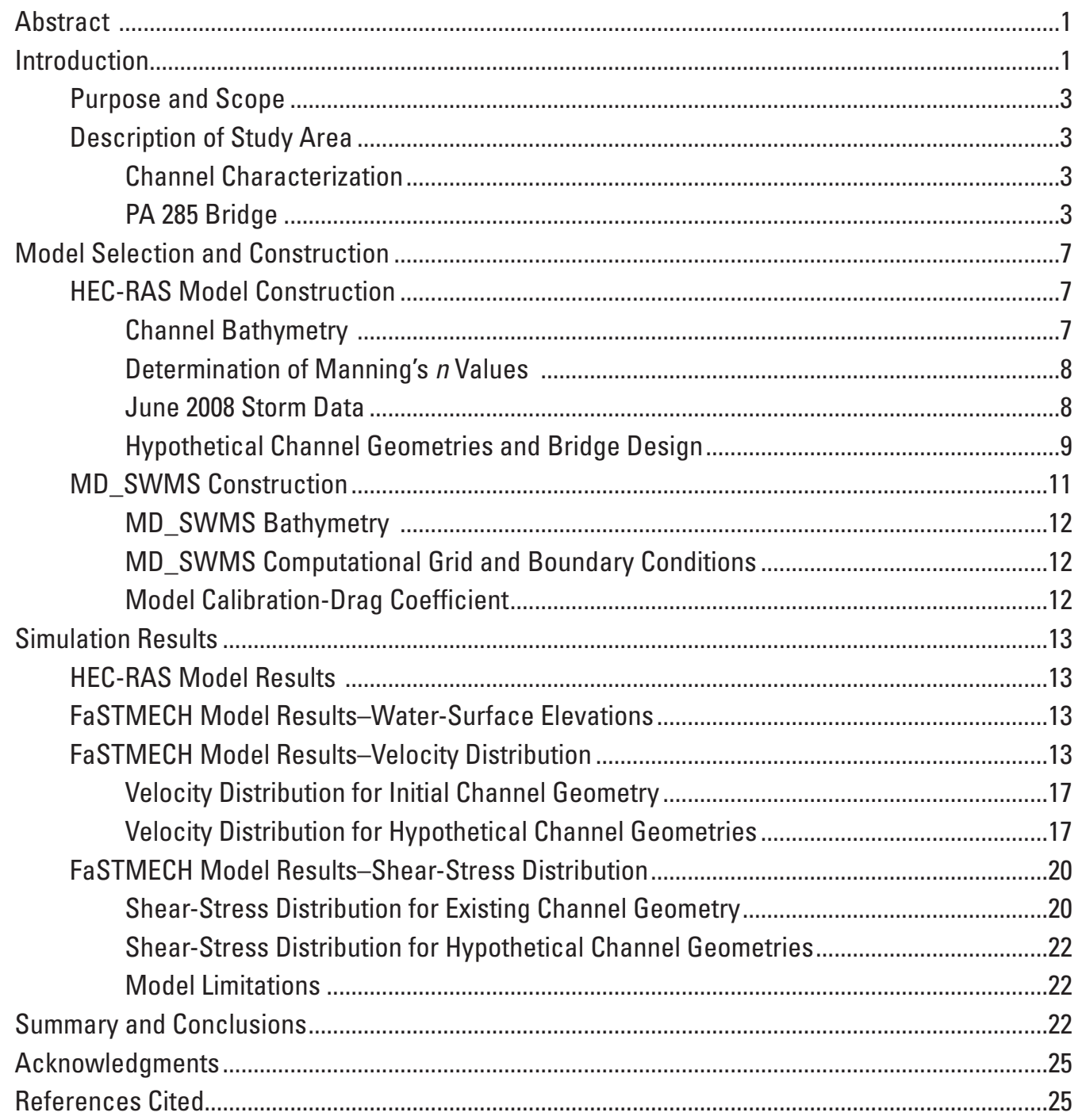




\section{Figures}

1. Map showing location of Wymans Run watershed, Crawford County, Pa

2. Photographs showing channel and bank variation within the Wymans Run watershed, Crawford County, $\mathrm{Pa}$. (A) approximately 200 feet upstream from the PA 285 bridge, looking downstream, $(B)$ approximately 300 feet upstream from the PA 285 bridge, looking upstream, $(C)$ approximately 400 feet upstream from the PA 285 bridge, looking upstream, and $(D)$ upper watershed looking downstream

3. Maps showing locations of cross sections used for the Hydrologic Engineering Centers River Analysis System model and sediment surveys, including a detailed view in the vicinity of the bridge on Wymans Run, Crawford County, Pa.

4. Photographs showing Wymans Run, Crawford County, Pa., $(A)$ upstream from the PA 285 bridge and $(B)$ upstream from the PA 285 bridge after the June 5, 2008, storm.

5. Graph showing elevations at cross section 1212,40 feet upstream from the bridge on Wymans Run, Crawford County, Pa., before June 2008 storm determined from field-survey and using LIDAR data

6. Graphs showing elevations for Wymans Run study reach, Crawford County, Pa., used for modeling the initial channel, expanded bridge or widened channel, and dredged channel scenarios. The cross sections surveyed after the June 2008 storm are also shown for cross sections $(A) 1,141,(B) 1,175,(C) 1,212,(D) 1,261$, (E) 1,341, and $(F) 1,378$ upstream from French Creek.

7. Graph showing water-surface elevations recorded on June 5, 2008, by the installed transducer and high-water mark found inside the transducer housing,

Wymans Run, Crawford County, Pa...

8. Graph showing elevations of the channel bed, Wymans Run, Crawford County, Pa., for the initial channel and the two dredged channel geometries as depicted in the Hydraulic Engineering Centers River Analysis System

9. Maps showing Multi-Dimensional Surface-Water Modeling System drag coefficients determined for the Wymans Run study reach, Crawford County, Pa., $(A)$ using sediment sizes determined from field surveys and depth determined from a model run at a streamflow of 1,000 cubic feet per second, $(B)$ actual drag coefficients used for the initial channel geometry, $(C)$ close up of drag coefficients used in the widened channel geometry, and $(D)$ close up of drag coefficients used in the dredged 50 channel geometry.

10. Graph showing surveyed high-water marks after the June 2008 storm, and the Multi-Dimensional Surface-Water Modeling System simulated initial water-surface elevation and various elevations for a streamflow of 1,000 cubic feet per second, Wymans Run study reach, Crawford County, Pa.

11. Graph showing surveyed high-water marks after the June 2008 storm, the simulated Hydrologic Engineering Centers River Analysis System water-surface elevation for a streamflow of 1,000 cubic feet per second, and elevation of the left bank, Wymans Run study reach, Crawford County, Pa.

12. Graph showing Flow and Sediment Transport and Morphological Evolution of Channels model simulated initial water-surface elevation and the simulated water-surface elevations for hypothetical geometries for a streamflow of 1,000 cubic feet per second, Wymans Run study area, Crawford County, Pa.

13. Graph showing variation of the Hjulström diagram showing streamflow in relation to grain size 
14. Maps showing Flow and Sediment Transport and Morphological Evolution of Channels model simulated stream velocities for a streamflow of $1,000 \mathrm{ft}^{3} / \mathrm{s}$ for the initial channel geometry, Wymans Run study reach, Crawford County, Pa

15. Maps showing Flow and Sediment Transport and Morphological Evolution of Channels model simulated velocity for $(A)$ the expanded bridge, $(B)$ the widened channel, $(C)$ the stream channel dredged 50 feet upstream, and $(D)$ the stream channel dredged 200 feet upstream for a streamflow of 1,000 cubic feet per second, Wymans Run study reach, Crawford County, $\mathrm{Pa}$....

16. Maps showing Flow and Sediment Transport and Morphological Evolution of Channels model predicted largest mobile sediment size based upon critical boundary shear stress values for each sediment class at a streamflow of 1,000 cubic feet per second for the initial channel geometry, Wymans Run study reach, Crawford County, $\mathrm{Pa}$

17. Maps showing Flow and Sediment Transport and Morphological Evolution of Channels model largest mobile sediment size based upon critical boundary shear stress values for each sediment class at a streamflow of 1,000 cubic feet per second for $(A)$ the expanded bridge, $(B)$ the widened channel, $(C)$ the stream channel dredged $50 \mathrm{ft}$ upstream from the bridge, and $(D)$ the stream channel dredged $200 \mathrm{ft}$ upstream from the bridge, Wymans Run study reach, Crawford County, Pa.. 


\section{Tables}

1. Results of sediment surveys and Manning's $n$ calculations at selected cross sections in the Wymans Run study reach, Crawford County, Pa.

2. Flow and Sediment Transport and Morphological Evolution of Channels model simulated water-surface elevations for the initial channel geometry and elevation differences between the initial geometry and the hypothetical channel geometries for a streamflow of 1,000 cubic feet per second at selected cross sections, Wymans Run study area, Crawford County, $\mathrm{Pa}$.

3. Flow and Sediment Transport and Morphological Evolution of Channels model maximum simulated velocity for the initial and hypothetical channel geometries for a streamflow of 1,000 cubic feet per second at selected cross sections, Wymans Run, Crawford County, Pa...

4. Sediment grade scale, Shields parameter, and critical shear-stress ranges for each sediment class 


\section{Conversion Factors}

\begin{tabular}{|c|c|c|}
\hline Multiply & By & To obtain \\
\hline \multicolumn{3}{|c|}{ Length } \\
\hline inch (in.) & 2.54 & centimeter $(\mathrm{cm})$ \\
\hline inch (in.) & 25.4 & millimeter (mm) \\
\hline foot $(\mathrm{ft})$ & 0.3048 & meter $(\mathrm{m})$ \\
\hline mile (mi) & 1.609 & kilometer (km) \\
\hline centimeter $(\mathrm{cm})$ & 0.3937 & inch (in.) \\
\hline millimeter $(\mathrm{mm})$ & 0.03937 & inch (in.) \\
\hline meter $(\mathrm{m})$ & 3.281 & foot $(\mathrm{ft})$ \\
\hline kilometer $(\mathrm{km})$ & 0.6214 & mile (mi) \\
\hline \multicolumn{3}{|c|}{ Area } \\
\hline square mile $\left(\mathrm{mi}^{2}\right)$ & 259.0 & hectare (ha) \\
\hline square mile $\left(\mathrm{mi}^{2}\right)$ & 2.590 & square kilometer $\left(\mathrm{km}^{2}\right)$ \\
\hline hectare (ha) & 0.003861 & square mile $\left(\mathrm{mi}^{2}\right)$ \\
\hline square kilometer $\left(\mathrm{km}^{2}\right)$ & 0.3861 & square mile $\left(\mathrm{mi}^{2}\right)$ \\
\hline \multicolumn{3}{|c|}{ Volume } \\
\hline cubic foot $\left(\mathrm{ft}^{3}\right)$ & 0.02832 & cubic meter $\left(\mathrm{m}^{3}\right)$ \\
\hline cubic decimeter $\left(\mathrm{dm}^{3}\right)$ & 0.03531 & cubic foot $\left(\mathrm{ft}^{3}\right)$ \\
\hline cubic meter $\left(\mathrm{m}^{3}\right)$ & 35.31 & cubic foot $\left(\mathrm{ft}^{3}\right)$ \\
\hline \multicolumn{3}{|c|}{ Flow rate } \\
\hline cubic foot per second $\left(\mathrm{ft}^{3} / \mathrm{s}\right)$ & 0.02832 & cubic meter per second $\left(\mathrm{m}^{3} / \mathrm{s}\right)$ \\
\hline cubic meter per second $\left(\mathrm{m}^{3} / \mathrm{s}\right)$ & 35.31 & cubic foot per second $\left(\mathrm{ft}^{3} / \mathrm{s}\right)$ \\
\hline
\end{tabular}

Vertical coordinate information is referenced to the North American Vertical Datum of 1988 (NAVD 88). 



\title{
Simulations of Flow and Prediction of Sediment Movement in Wymans Run, Cochranton Borough, Crawford County, Pennsylvania
}

\author{
By Elizabeth Hittle
}

\begin{abstract}
In small watersheds, runoff entering local waterways from large storms can cause rapid and profound changes in the streambed that can contribute to flooding. Wymans Run, a small stream in Cochranton Borough, Crawford County, experienced a large rain event in June 2008 that caused sediment to be deposited at a bridge. A hydrodynamic model, Flow and Sediment Transport and Morphological Evolution of Channels (FaSTMECH), which is incorporated into the U.S. Geological Survey Multi-Dimensional Surface-Water Modeling System (MD_SWMS) was constructed to predict boundary shear stress and velocity in Wymans Run using data from the June 2008 event. Shear stress and velocity values can be used to indicate areas of a stream where sediment, transported downstream, can be deposited on the streambed. Because of the short duration of the June 2008 rain event, streamflow was not directly measured but was estimated using U.S. Army Corps of Engineers one-dimensional Hydrologic Engineering Centers River Analysis System (HEC-RAS). Scenarios to examine possible engineering solutions to decrease the amount of sediment at the bridge, including bridge expansion, channel expansion, and dredging upstream from the bridge, were simulated using the FaSTMECH model. Each scenario was evaluated for potential effects on water-surface elevation, boundary shear stress, and velocity.
\end{abstract}

\section{Introduction}

Wymans Run (local name) in Cochranton Borough, Crawford County, Pa., drains an area of approximately 4 square miles $\left(\mathrm{mi}^{2}\right)$ and discharges to French Creek approximately $600 \mathrm{ft}$ upstream from the confluence of Little Sugar Creek and French Creek in Crawford County, Pa. (fig. 1). Sedimentation and flooding within and along Wymans Run have been a persistent problem. In an attempt to mitigate damage to property and infrastructure, the reaches immediately upstream from the confluence with French Creek were dredged until 1979 when consistent dredging operations were discontinued. Since that time, dredging has been performed occasionally; the sediment problems have not abated. On July 21, 2003, a severe mesoscale convective weather system delivered more than 4 inches (in.) of rain within 24 hours; the maximum intensity of 2.5 in. fell in 1.5 hours on the Borough of Cochranton, Pa., and surrounding areas. Along Steen Hill Road just above the junction with PA 285 (fig. 1), severe flooding caused damage to homes and property. Substantial sediment build-up in Wymans Run underneath the PA 285 bridge was noted after this storm, and residents were concerned that this build-up of sediment decreased the conveyance of the bridge causing backwater and likely making the flooding worse.

Simulations of streamflow and backwater can lead to a better understanding of how structures, such as bridges, in waterways affect the natural streamflow characteristics and flood peaks. One aspect of the mission of the U.S. Geological Survey (USGS) is to provide reliable scientific information that describes natural systems and helps to minimize the loss of life and property that may be impacted by natural hazards. Studies in small watersheds, such as Wymans Run, follow the guidelines within our strategic science direction that the USGS works with its cooperative partners to ensure that simulation methods can be effectively applied in all situations to better understand the natural system. This study by the USGS, in cooperation with Crawford County Conservation District and Fairfield Township, Pennsylvania, examines the effects of possible engineering solutions to decrease the amount of sediment that is built up underneath the bridge in order to reduce upstream flooding.

Two models were constructed to represent hydraulic conditions in the stream using (1) the U.S. Army Corps of Engineers (USACE) Hydrologic Engineering Centers River Analysis System (HEC-RAS) and (2) a hydrodynamic model, Flow and Sediment Transport and Morphological Evolution of Channels (FaSTMECH), which is incorporated into the U.S. Geological Survey Multi-Dimensional Surface-Water Modeling System (MD_SWMS). High-water marks from a heavy precipitation event occurring on June 5, 2008, were used for model calibration. HEC-RAS was used to predict streamflow for the 2008 rainfall event and prepare cross sections of the stream for input to MD_SWMS. Predicted boundary shear stress and velocity from FaSTMECH were used to evaluate the potential sediment transport and deposition within the stream. 

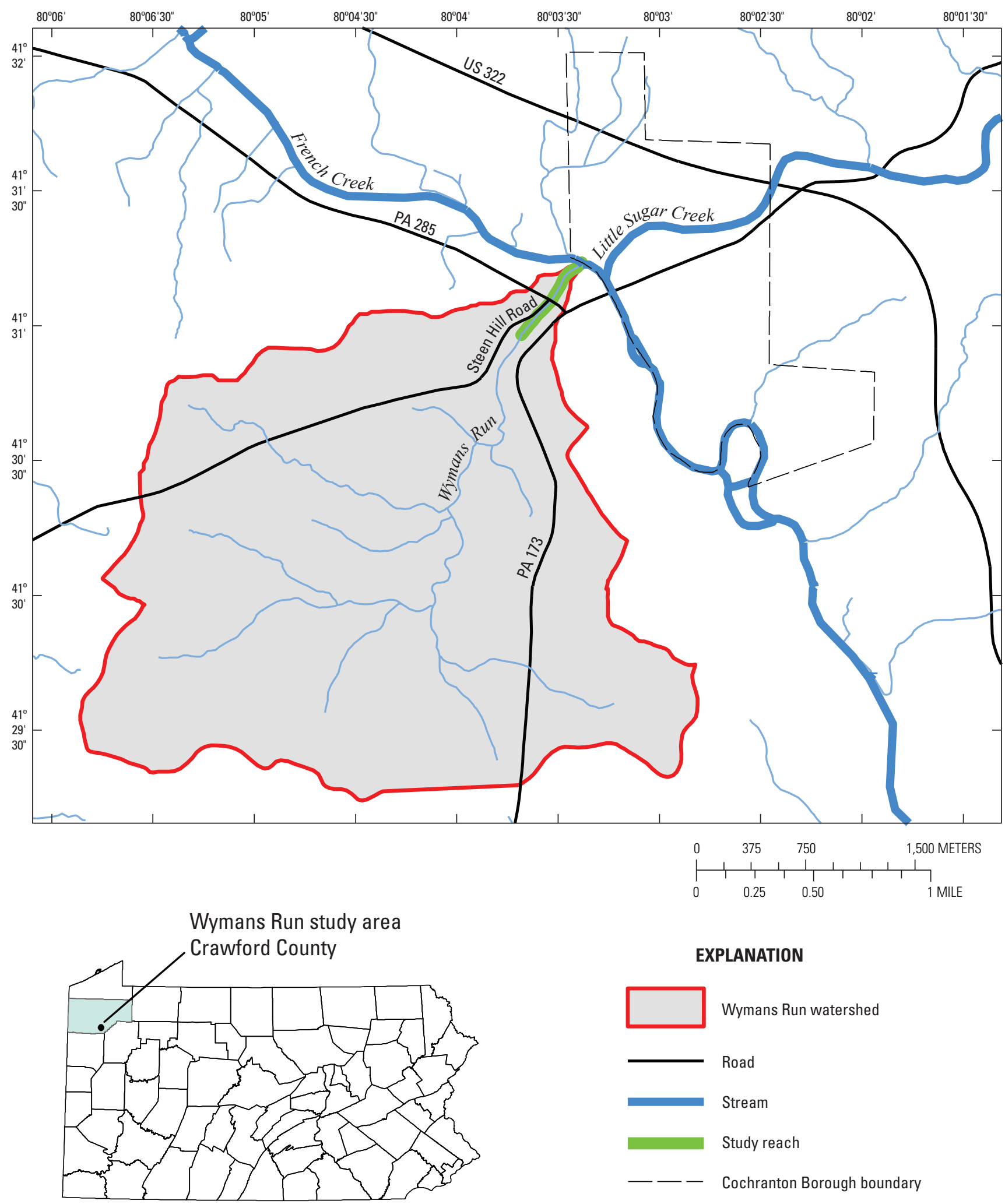

EXPLANATION

Pennsylvania

Figure 1. Location of Wymans Run watershed, Crawford County, Pa. 


\section{Purpose and Scope}

This report discusses the modeling efforts undertaken to describe the hydraulic characteristics of Wymans Run, the sediment transport that can occur, and the effects of engineering solutions proposed by others that were designed to minimize upstream flooding and reduce sedimentation at the bridge. The scenarios simulated are expansion of the PA 285 bridge, channel widening directly upstream and downstream from the bridge, and deepening of the channel upstream from the bridge. The main objectives of this report are to describe the simulated water-surface elevation, velocity distribution, and shear-stress distribution throughout the study reach for four channel geometry configurations and a proposed geometry of the PA 285 bridge. The modeling results show the potential effects that expanding the PA 285 bridge and dredging the channel would have on the boundary shear stress and velocity in the channel just upstream from the PA 285 bridge. The scope of this report includes definitions of the stream geometry and streambed-sediment characteristics, documentation for the construction of the models used for the study reach, and a presentation of the results of the models for actual and hypothetical channel configurations.

\section{Description of Study Area}

Wymans Run is in the Northwestern Glaciated Plateau Section of the Appalachian Plateaus Physiographic Province (Sevon, 2000) approximately $0.5 \mathrm{mi}$ west of Cochranton Borough in Fairfield Township, Crawford County, Pa. It drains an area of approximately $4 \mathrm{mi}^{2}$ and discharges to French Creek, approximately $600 \mathrm{ft}$ upstream from the confluence of Little Sugar Creek and French Creek (fig. 1).

The headwaters of Wymans Run drain relatively flat open fields with poorly drained soils, predominantly of the Cambridge and Venango series (Yaworski and others, 1979). These soil series are characterized by low permeability that facilitates runoff and concentrates stormwater into various rills and channels. The lower part of the watershed is wooded and has some steep valleys that are prone to mass wasting through downslope movement of rock and soil overlying shale bedrock. Glacial drift, an unconsolidated erosion-prone mixture of clay, silt, sand, and gravel, overlays the bedrock in most places and is up to $75 \mathrm{ft}$ thick. Topographic lows along the main channel and tributaries are underlain primarily by shale bedrock of the Shenango and Cuyahoga Groups, and the ridges are underlain by conglomeratic sandstone of the Pottsville Group (Geyer and Wilshusen, 1982).

\section{Channel Characterization}

The study reach of Wymans Run extends from French Creek to approximately 2,000 ft upstream from the PA 285 bridge. On the basis of channel-bed elevations surveyed at the PA 285 bridge and $600 \mathrm{ft}$ upstream, the slope of the channel upstream from the bridge is about $0.014 \mathrm{ft} / \mathrm{ft}$. Downstream from the bridge, on the basis of channel-bed elevations surveyed at the bridge and $600 \mathrm{ft}$ downstream, the slope is about $0.010 \mathrm{ft} / \mathrm{ft}$. The width of the channel is highly variable, but on average bankfull width is approximately $28 \mathrm{ft}$ on the downstream side of the bridge and $32 \mathrm{ft}$ on the upstream side of the bridge. Throughout the entire channel, but within this reach specifically, the composition of the channel bed is extremely variable in sediment size, both laterally within a cross section and longitudinally (figs. 2A-C). In the upstream part of the watershed, many highly unstable banks (fig. 2D) provide nearly unlimited sediment that has the potential to be transported downstream. Depositional features such as point bars are visible throughout the channel. The banks of the channel are generally overgrown with vegetation, including thick bushes and small trees. In some parts of the stream, the banks have been artificially armored with large boulders for erosion prevention (fig. 2A).

Sediment sampling was conducted at selected cross sections on June 29, 2006 and July 5, 2006, to assist with the determination of channel roughness characteristics. Sedimentsize analysis, using 100 particle sampling methods, and channel surveys, consisting of a determination of bankfull channel elevation, were completed at selected cross sections (fig. 3). Note that the study reach is a highly dynamic system; the configuration and composition of the channel bottom have the potential to be altered during major rain events. Streamchannel conditions observed on June 26, 2006, and on June 25, 2008, following a storm event that occurred in June 2008 are shown in figure 4 . The sediment surveys conducted in June and July 2006 can only indicate the conditions at that time and may not represent the stream conditions at a later date. It is expected that the size of the sediment will be similar because the source material will not have changed; however, the placement of the material may be different.

\section{PA 285 Bridge}

The PA 285 bridge is a steel beam bridge sitting atop reinforced concrete abutments. The bridge opening is $41 \mathrm{ft}$ with a minimum designed underclearance of $3.6 \mathrm{ft}$. The roadway width is $34 \mathrm{ft}$. During substantial storms, sediment builds up on the upstream side of the bridge, preferentially on the left side looking downstream (fig. 4). During the June 2008 storm, sediment built up so the minimum clearance was $3.4 \mathrm{ft}$ compared to a clearance of about $7 \mathrm{ft}$ in the same spot when surveys were done 2 years earlier. This bridge is slated to be replaced with a concrete spread box bridge with beams on integral abutments. The bridge span will be about $15 \mathrm{ft}$ wider and $1.5 \mathrm{ft}$ higher (Quality Engineering Solutions, Inc., written commun., November 2010), 


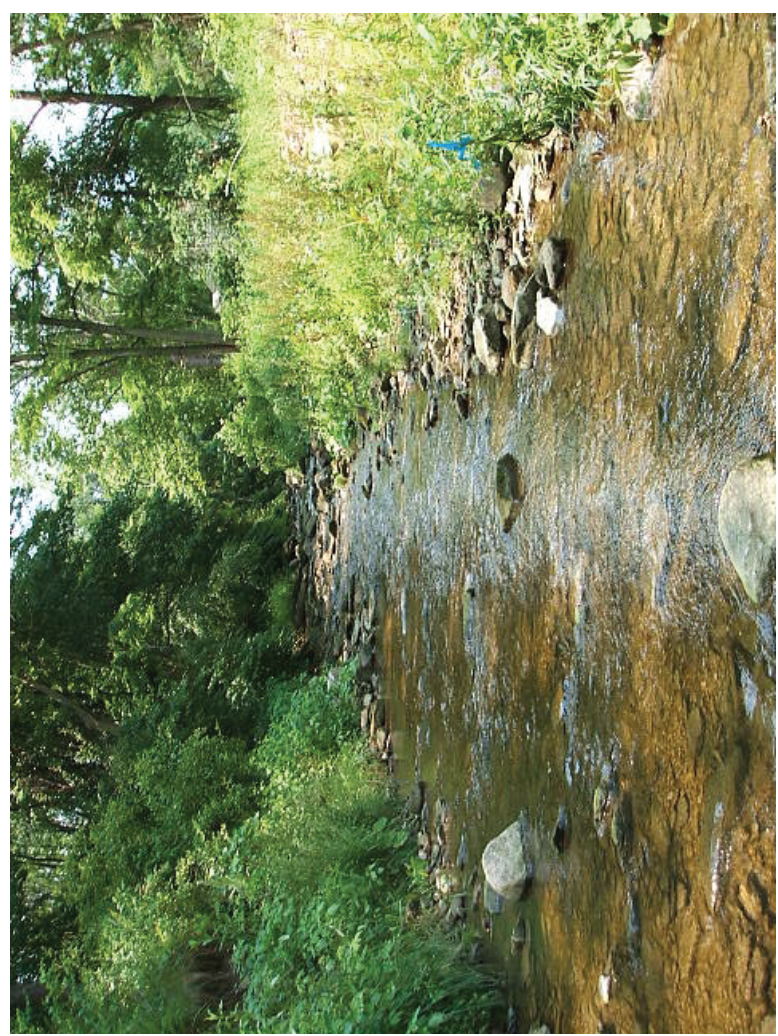

$\infty$

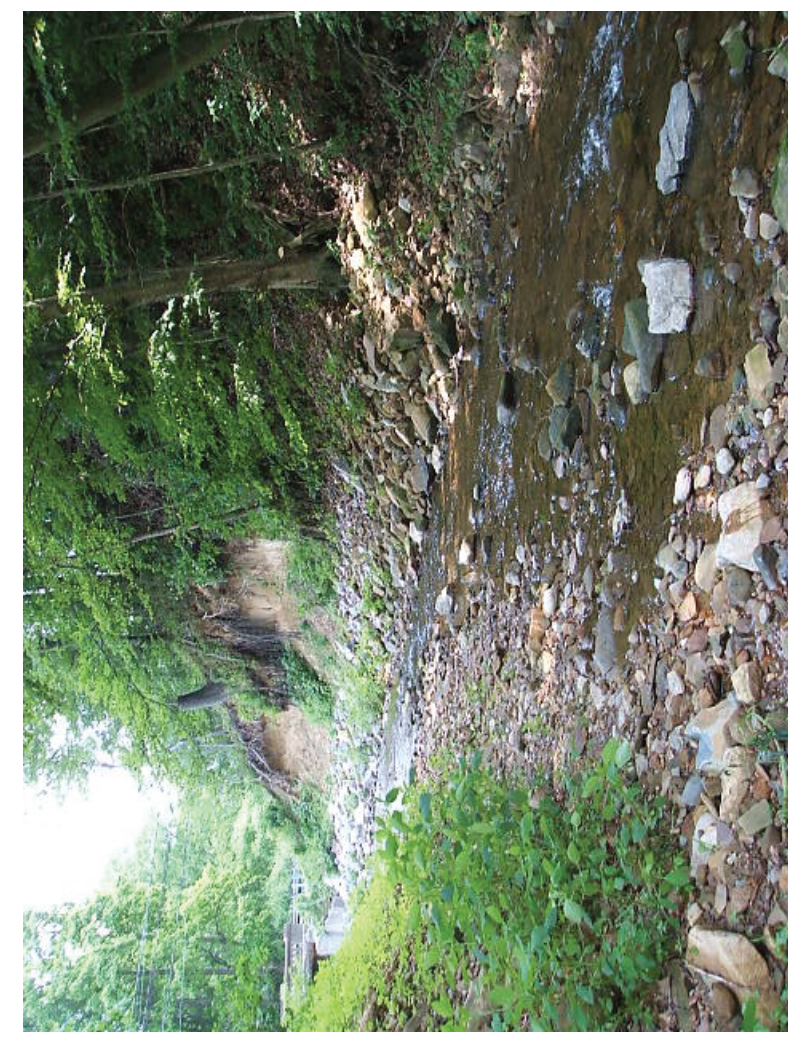

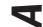
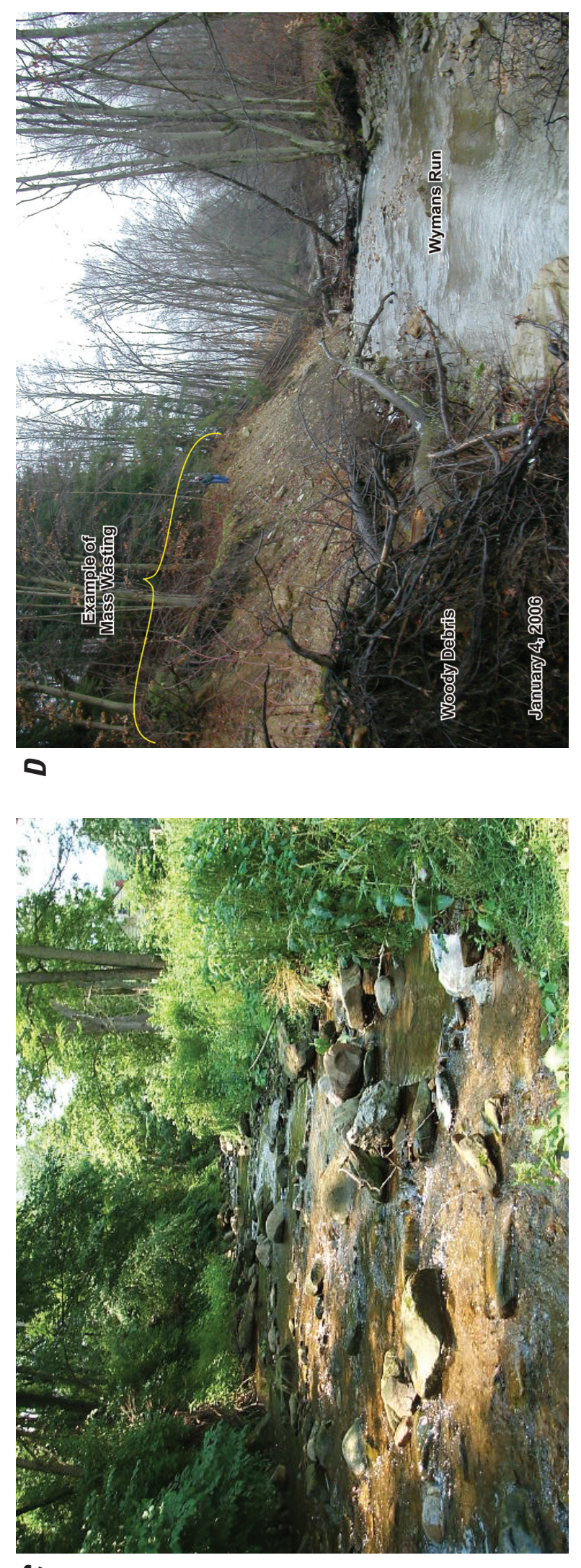

ט

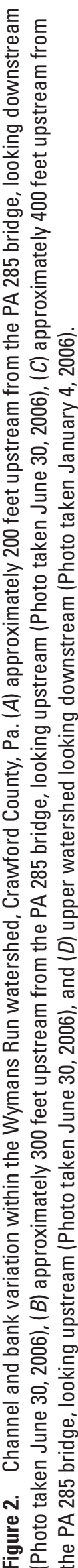




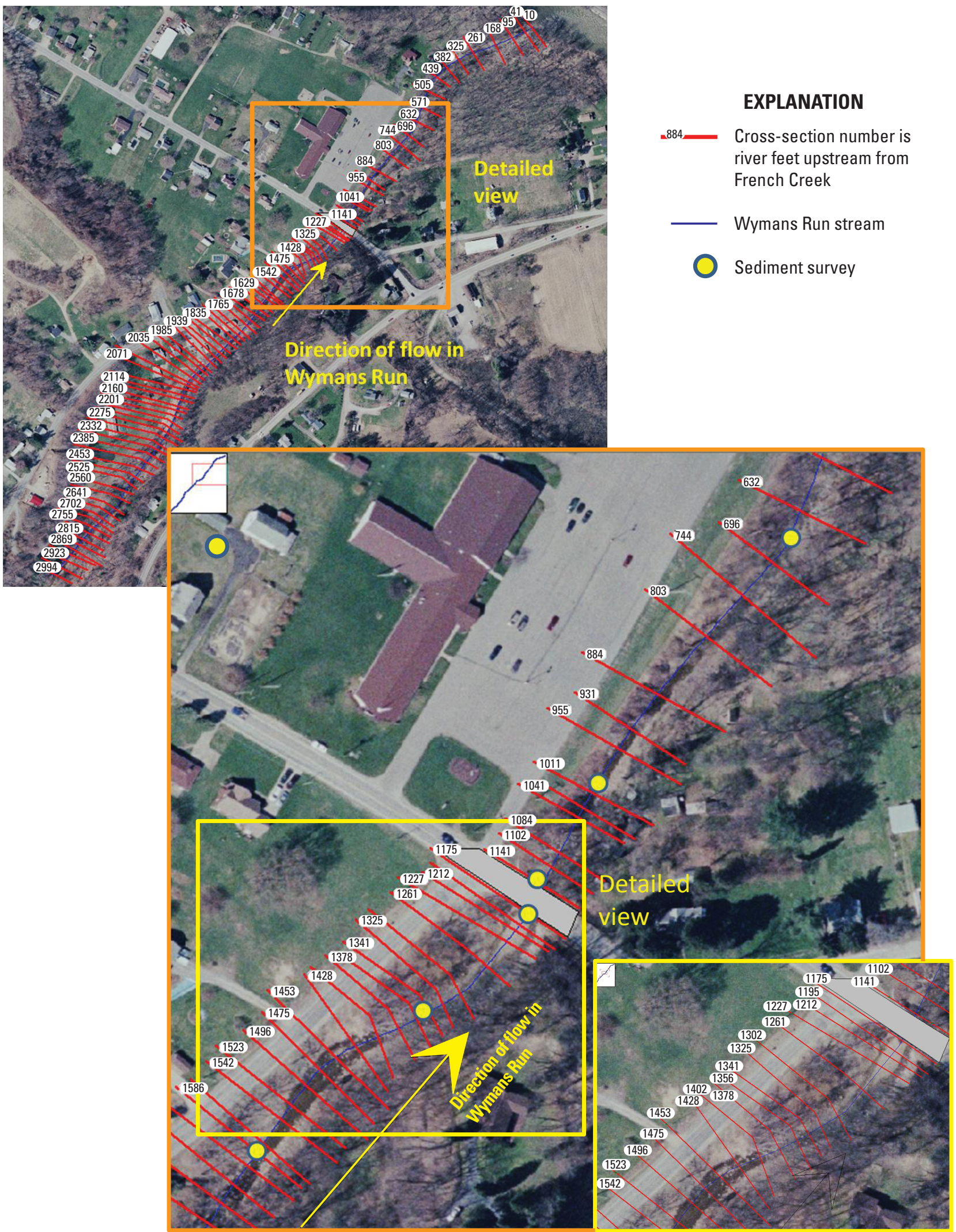

Figure 3. Locations of cross sections used for the Hydrologic Engineering Centers River Analysis System model and sediment surveys, including a detailed view in the vicinity of the bridge on Wymans Run, Crawford County, Pa. 


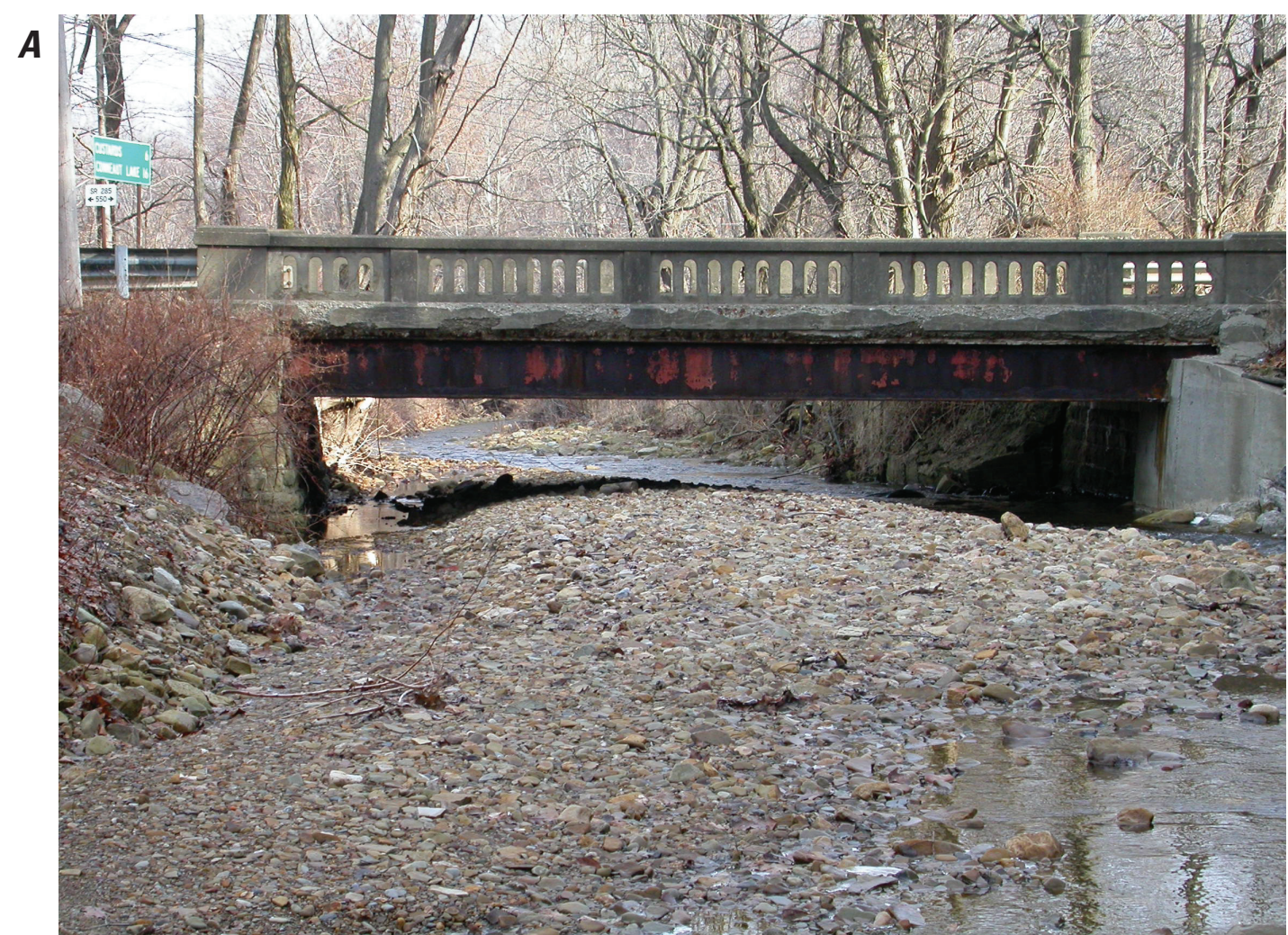

B

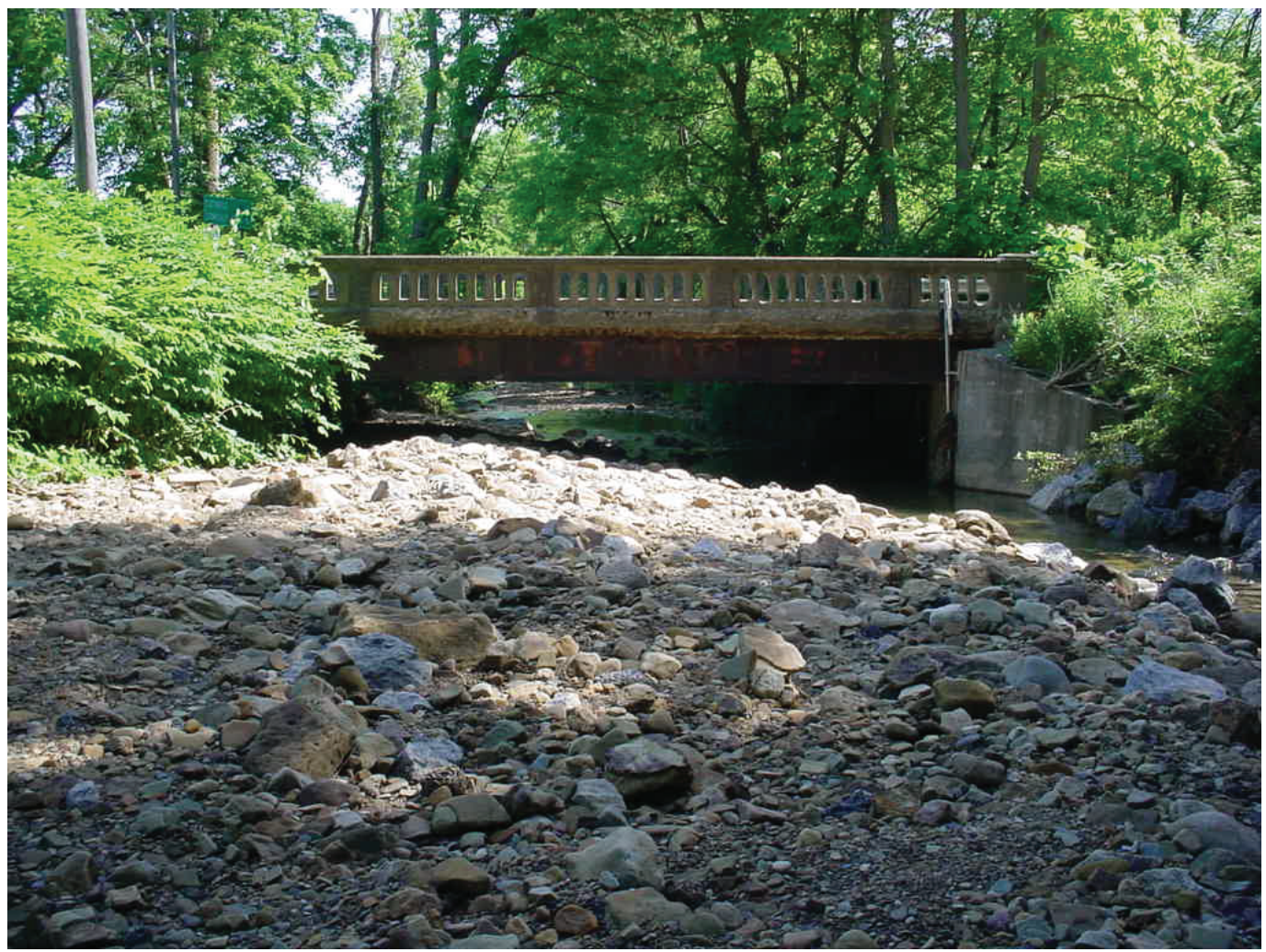

Figure 4. Wymans Run, Crawford County, Pa., $(A)$ upstream from the PA 285 bridge (Photo taken on January 23, 2006) and $(B)$ upstream from the PA 285 bridge after the June 5, 2008, storm (Photo taken on June 25, 2008). 


\section{Model Selection and Construction}

One model and one modeling system were used for this study, HEC-RAS and MD_SWMS, respectively. HEC-RAS, version 4.0.0 (U.S. Army Corps of Engineers, 2008) is a onedimensional hydraulic model that was used to estimate streamflow during the heavy June 5, 2008, rain event for which field-measured streamflow was not available. HEC-RAS has easy to use cross-section editing and interpolation routines that were used when designing the channel and bridge modification scenarios. HEC-RAS version 4.0.0 also includes a sedimentrouting routine; however, insufficient bedload data prohibited the application of that routine. MD_SWMS version 2.3.5b (McDonald and others, 2005) is a GUI interface modeling system which incorporates several models. One such model is the Flow and Sediment Transport and Morphological Evolution of Channels (FaSTMECH) (Nelson and others, 2003), a twodimensional hydraulic model that can be used to calculate the distribution of shear stress and velocity continuously across a channel. FaSTMECH was used in this study to evaluate the potential for sediment erosion and deposition in the stream channel, specifically in the area of the PA 285 bridge. Continuous horizontal distribution is important in Wymans Run because of the preferential sediment deposition seen on one side or the other in the channel.

\section{HEC-RAS Model Construction}

HEC-RAS was designed to perform one-dimensional hydraulic calculations for a full network of natural and constructed channel cross-section profiles. The model contains river-analysis components for steady-flow water-surface elevation computations, unsteady flow simulation, and movable boundary sediment-transport computations. The unsteady flow and sediment portions of this software were not used because of insufficient field data. For this study, a HEC-RAS model was constructed to predict streamflow during a storm event in June 2008. Topographic data were collected from various sources to be used as input to the hydraulic models. Geographic Information System (GIS) coverages of the study area and field surveys conducted before the June storm were used to develop the model geometries. Field data, including particle-size sediment surveys, were used to estimate hydraulic characteristics such as Manning's $n$. The steady-flow analysis routines were utilized with the boundary conditions set to normal depth, based upon the calculated slope of the channel upstream and downstream from the bridge. The cross-section editing and interpolation routines within HEC-RAS were used to modify the existing original cross sections to represent the hypothetical stream-geometry scenarios and potential bridge design suggested by the Pennsylvania Department of Transportation.

\section{Channel Bathymetry}

Hydraulic models require accurate topographic data so that stream conditions can be accurately simulated. Light Detection And Ranging (LiDAR) data (www.pasda.psu.edu) collected in 2007 were used for the base topographic map for development of the model geometry. LiDAR data were supplemented with cross-sectional field surveys conducted within the channel upstream from the PA 285 bridge. Field surveys were conducted downstream from the bridge in July 2006 and upstream from the bridge in August and November 2007 using a Trimble Total Station and Sokkia laser level and translated to North American Vertical Datum of 1988 (NAVD88). These field-surveyed cross sections were particularly useful in the area of the bridge where large differences between the field survey data and LiDAR data were observed because the bridge created false ground elevations in the LiDAR data. The average difference between 321 field surveyed points and LiDAR derived points was $0.11 \mathrm{ft}$ with a standard error of $0.11 \mathrm{ft}$. However, there were a number of points that differed by more than $2 \mathrm{ft}$. This occurred primarily along the right edge of water where the bank is steep and heavily vegetated. An example of a cross-section comparison of elevations from the LiDAR data and surveyed data $40 \mathrm{ft}$ upstream from the bridge is shown in figure 5.

The USACE HEC-GeoRAS tool for ArcGIS (version 4.2.92 for ArcGIS 9.2; U.S. Army Corps of Engineers, 2009) was used to develop cross sections for use within HEC-RAS. HEC-GeoRAS is a set of procedures, tools, and utilities that allows for elevation data to be imported directly into HEC-RAS from ArcGIS. A digital terrain model of the area is required to provide elevations of themes such as cross-section cut lines, stream centerline, and main channel banks. If landuse coverage is imported into ArcGIS, Manning's $n$ values can be assigned to different land uses. Manning's $n$ values can then be assigned to different portions of cross-section cut lines. LiDAR data were downloaded as a 1-m raster Digital Elevation Model that was brought directly into ArcGIS to develop the topographic data. Relevant data, such as the left and right banks, land use (for overbank Manning's $n$ determination), and lines for cross sections, were digitized using HEC-GeoRAS extensions. Cross-section lines were drawn approximately 25 to $50 \mathrm{ft}$ apart from each other longitudinally throughout the stream reach and extending into the flood plain as shown in figure 3. The cross-section designation (for example, 1011) is based on distance (in feet) upstream on Wymans Run from the confluence of Wymans Run and French Creek along the designated centerline. The elevation and stationing data associated with these cross sections were then imported into HEC-RAS for model use.

The cross sections created in HEC-GeoRAS from LiDAR data were modified in HEC-RAS based on field-surveyed cross sections directly upstream and downstream from the bridge. Field surveyed elevation and stationing were used at these locations because of the false ground elevations observed near the bridge in the LiDAR data. Field surveys 


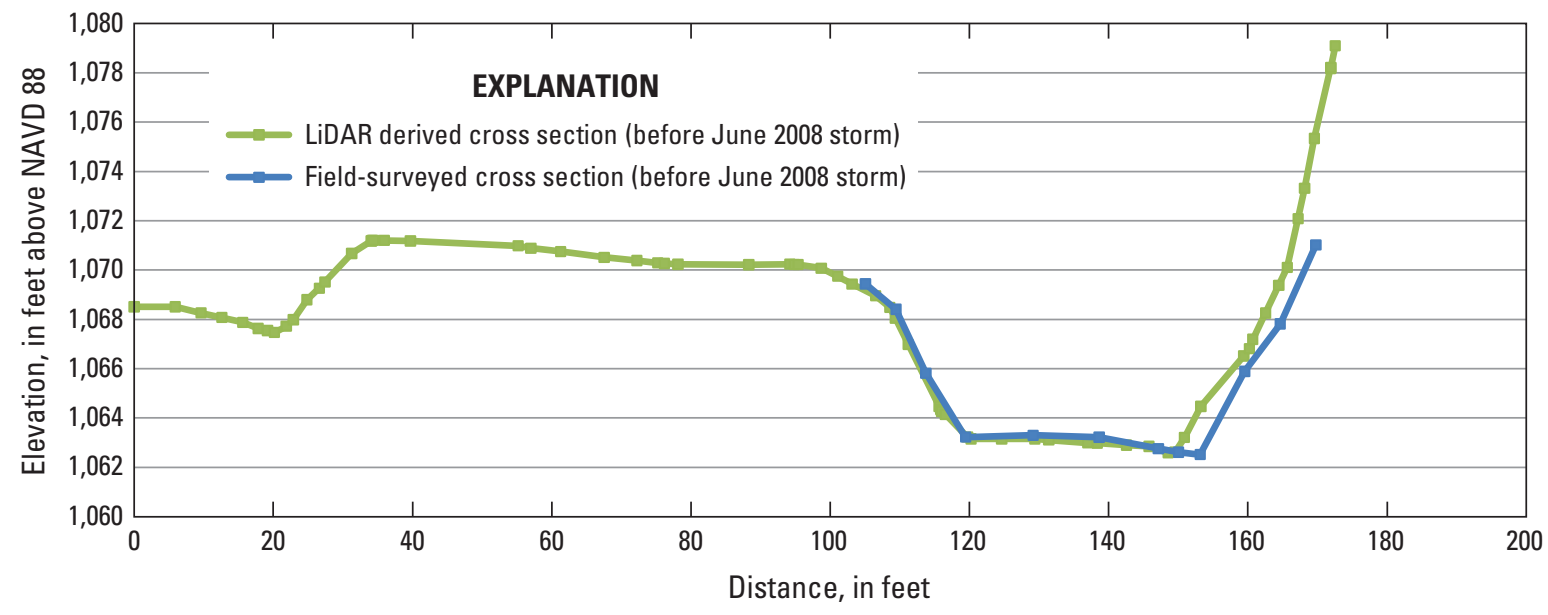

Figure 5. Elevations at cross section 1212, 40 feet upstream from the bridge on Wymans Run, Crawford County, Pa., before June 2008 storm determined from field-survey and using LIDAR data.

also were used to confirm elevations of the top of the bank. The differences between the field-surveyed and LIDAR elevations were greater for the top of the bank points than for other points because the banks are steep and vegetated. The surveyed point, if available, was used for the left bank elevation in the graphs from the bridge up to cross section 1967. The average difference in left top of bank elevation was $0.58 \mathrm{ft}$ with a standard error of $0.17 \mathrm{ft}$. Interpolation of cross sections was accomplished using the cross-section interpolation routines within HEC-RAS so that there was no more than $2 \mathrm{ft}$ between cross sections. These interpolated cross sections were imported into MD SWMS for model construction.

\section{Determination of Manning's $n$ Values}

Manning's roughness coefficient represents the flow resistance in a channel. Factors that affect flow resistance are (1) size, gradation, and angularity of materials composing the streambed; (2) channel shape; (3) type of bed forms (for example, channel dunes, antidunes, and ripples); (4) presence of sand bars; (5) riparian vegetation; (6) obstructions (for example, bridges, causeways, and vegetation); (7) presence of suspended sediment and movement of bedload; and (8) degree of meandering. In general, resistance decreases as flow depth increases; resistance also decreases as the size of the bed material decreases (Arcement and Schneider, 1984).

Using data from the sediment surveys, Manning's $n$ values were calculated using the Rosgen method (Rosgen, 1998). The Rosgen method describes the relation of channel bed-particle size to hydraulic resistance for river data from a variety of eastern and western streams. It uses the ratio of field collected hydraulic mean depth (d) to D84 values (size of material, in millimeters, for which 84 percent of the material is finer) as an initial field variable to calculate a resistance factor (mean velocity/shear velocity ratio) that is then related to Manning's $n$. Derived values of Manning's $n$ are presented in table 1.

In an effort to use the HEC-RAS model to match watersurface elevation profile data, Manning's $n$ roughness coefficients were adjusted for selected reaches and streambanks. In the straight channel-controlled sections of the study reach, the size, gradation, and angularity of the materials composing the streambed may be more influential than other factors in determining flow resistance. On the basis of sediment surveys, three regions of Manning's $n$ values were field determined using equations from Rosgen (1998) and the field surveyed D84 values for bed-sediment material. The Manning's $n$ value for the reach upstream from the bridge was calculated as 0.05 , downstream was 0.044 , and at the bridge was 0.03 . Adjustments to Manning's $n$ were made to the average channel Manning's $n$ of 0.04 for the banks of the stream because of vegetation. A reasonable adjustment for vegetation ranges from 0.01 to 0.025 , which is added to the base value (Arcement and Schneider, 1984) The left bank tended to be more vegetated, especially farther upstream from the bridge. The stream banks and flood plain were assigned a consistent value of 0.06 for the left bank and 0.05 for the right bank throughout the studied reach.

\section{June 2008 Storm Data}

To aid in the modeling of Wymans Run, a pressure transducer data logger was installed on August 28, 2007, inside a pipe on the upstream wingwall of the PA 285 bridge to record water-surface elevations at determined intervals. Owing to the placement of the pipe and the configuration of the channel, the transducer was out of the water during low-flow conditions. Stage data were recorded every 5 minutes and retrieved monthly. A crest-stage gage (CSG) was installed directly downstream from the PA 285 bridge on the left wingwall to 
Table 1. Results of sediment surveys and Manning's $n$ calculations at selected cross sections in the Wymans Run study reach, Crawford County, Pa.

["Bridge" refers to the PA 285 bridge over Wymans Run. Dnn is the particle-size index where "nn" is a particle size in millimeters. For example, D15 represents the size of material, in millimeters, for which 15 percent of the material is finer. $\mathrm{ft}$, feet; $\mathrm{mm}$, millimeters]

\begin{tabular}{|c|c|c|c|c|c|c|}
\hline & $\begin{array}{c}414 \mathrm{ft} \\
\text { above bridge } \\
(1,599 \mathrm{ft})\end{array}$ & $\begin{array}{c}182 \mathrm{ft} \\
\text { above bridge } \\
(1,357 \mathrm{ft})\end{array}$ & $\begin{array}{c}\text { Upstream } \\
\text { side of bridge } \\
(1,175 \mathrm{ft})\end{array}$ & $\begin{array}{c}\text { Downstream } \\
\text { side of bridge } \\
(1,141 \mathrm{ft})\end{array}$ & $\begin{array}{c}143 \mathrm{ft} \\
\text { below bridge } \\
(1,098 \mathrm{ft})\end{array}$ & $\begin{array}{c}487 \mathrm{ft} \\
\text { below bridge } \\
\text { (654 ft) }\end{array}$ \\
\hline Manning's $n$ & 0.049 & 0.050 & 0.027 & 0.029 & 0.047 & 0.041 \\
\hline Bankfull mean depth (ft) & 1.36 & 1.46 & ${ }^{1} 6.38$ & ${ }^{1} 5.54$ & 1.32 & 1.37 \\
\hline $\mathrm{D} 15(\mathrm{~mm})$ & 7.66 & 38.17 & 0.25 & 18.63 & 22.66 & 8.54 \\
\hline D35 (mm) & 47.77 & 61.30 & 1.38 & 37.63 & 48.29 & 22.88 \\
\hline D50 (mm) & 71.31 & 82.08 & 8.00 & 52.11 & 62.40 & 32.00 \\
\hline $\mathrm{D} 84(\mathrm{~mm})$ & 174.71 & 190.21 & 74.17 & 94.07 & 151.59 & 100.75 \\
\hline D95 (mm) & 401.68 & 298.55 & 116.30 & 192.00 & 216.75 & 189.42 \\
\hline
\end{tabular}

${ }^{1}$ Values are based on bridge geometry rather than bankfull geometry.

obtain high water marks. On June 5, 2008, 0.98 in. of rain fell during a 45-minute period according to weather records at the Meadville airport (KGKJ) $11 \mathrm{mi}$ away from the study area (Weather Underground, Inc., 2010). The resulting streamflow caused substantial changes throughout the entire channel (fig. 6). The precipitation amount is not from an official National Weather Service (NWS) station, but the daily total from Linesville (Linesville $1 \mathrm{~S}$ ), Pa., located about 20 miles away was 1.40 inches of precipitation (http://www.ncdc.noaa. gov/oa/climate/stationlocator.html). Recorded water-surface elevations from the transducer indicated the water-surface elevation increased about $2.5 \mathrm{ft}$ in 30 minutes. The peak stage was obtained from a high-water mark inside the transducer instrument housing and was about $0.6 \mathrm{ft}$ higher than the stage recorded by the transducer (fig. 7). The elevation data from the transducer are considered poor because the instrument was found flooded after the event, causing the pressure readings to be biased low, but the timing is considered reasonable.

Along with the measurement of high-water marks, cross sections located at the bridge and as much as $500 \mathrm{ft}$ upstream from the bridge were surveyed after the storm. Elevations at selected cross sections were compared between the crosssectional data before and after the storm and are shown in figure 6 . The cross sections surveyed after the storm were not used in the HEC-RAS model construction because the pre-storm cross sections are considered to be representative of the channel. After the storm, the channel had filled in significantly which most likely occurred during the stream recession. If significant scour had been observed upstream from the bridge, the post-storm cross sections would have been more representative.

\section{Hypothetical Channel Geometries and Bridge Design}

In June 2009, roadway engineers began design work to replace the existing PA 285 bridge. One of the modification scenarios includes raising the bridge deck and expanding the width of the bridge $10 \mathrm{ft}$ on the left bank. This proposed bridge modification was simulated in HEC-RAS by increasing the width of the channel geometry for two cross sections representing the downstream and upstream sides of the bridge accordingly. The first cross section $10 \mathrm{ft}$ upstream from the bridge also was modified for a more gentle transition from the proposed bridge opening to the existing stream. Raising the bridge deck in the simulation did not have any effect on the water-surface elevation as the modeled water surface never reached the bottom of the bridge decking. In the figures and in discussions, the modified bridge scenario is presented as "Expanded Bridge."

A second scenario considered was widening the channel upstream and downstream from the bridge to take advantage of the proposed expanded bridge width. The channel width was increased on the left bank about 15 to $20 \mathrm{ft}$ from cross section 1029 through cross section 1370 . The cross sections were modified so the channel was the same width as the bridge and then gradually transitioned back to the natural channel by cross section 1370 . The modified cross-section bathymetry for select cross sections as depicted in HEC-RAS is shown in figure 6 . The channel-bed elevation was not modified in this scenario. In figures and discussions, this scenario is presented as "Widened Channel."

Historically, when sediment was deposited underneath the PA 285 bridge, contractors were hired to remove bed material in the channel underneath and upstream from the bridge. To 

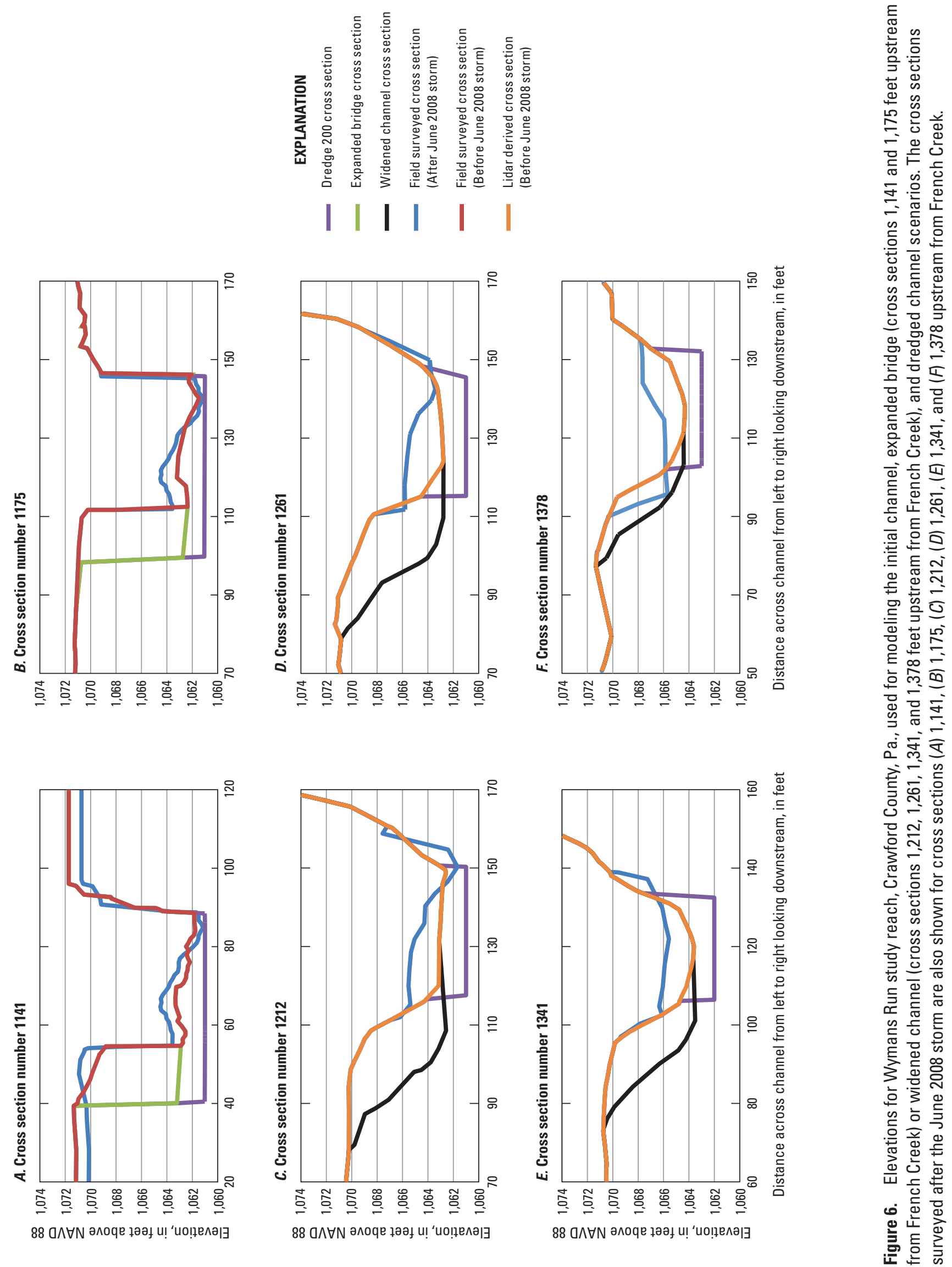


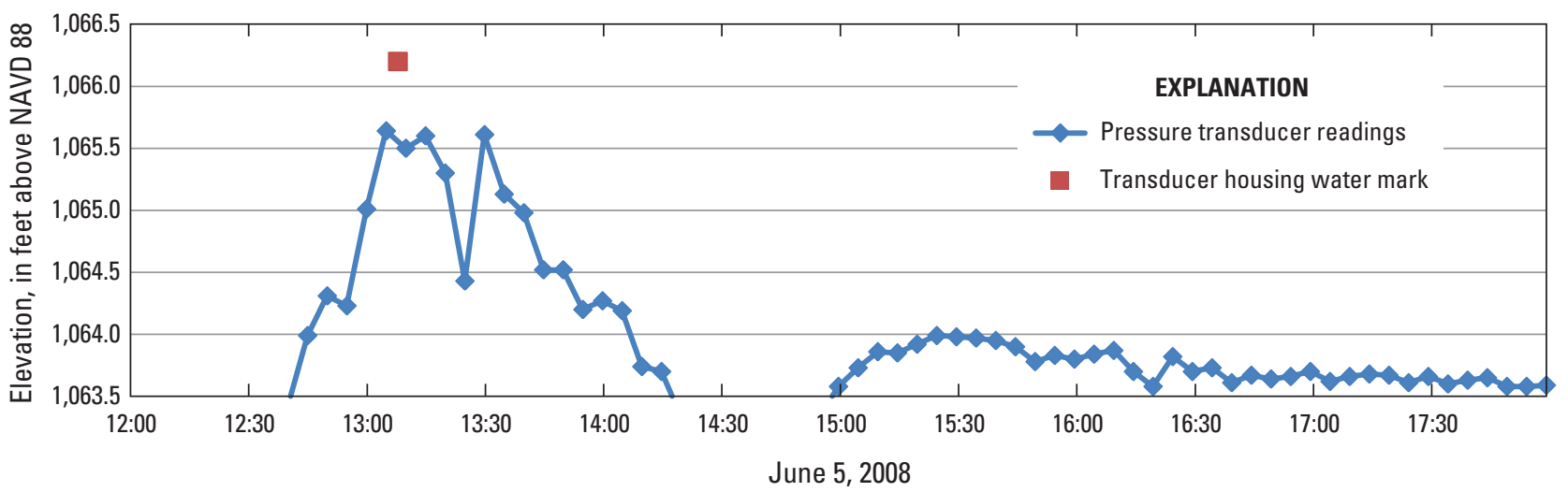

Figure 7. Water-surface elevations recorded on June 5, 2008, by the installed transducer and high-water mark found inside the transducer housing, Wymans Run, Crawford County, $\mathrm{Pa}$.

simulate this scenario, two additional models were constructed by modifying the channel geometry of cross sections from the bridge to (1) $50 \mathrm{ft}$ upstream, and (2) $200 \mathrm{ft}$ upstream. For all modified cross-section scenarios beginning at the bridge and continuing upstream $100 \mathrm{ft}$ (cross sections 1140-1302), the elevation of the channel bottom was set to the bed elevation underneath the bridge. From 100 to $150 \mathrm{ft}$ upstream from the bridge (cross sections 1324-1356), the elevation of the channel bottom was changed to $1 \mathrm{ft}$ above the elevation under the bridge and $2 \mathrm{ft}$ above for cross sections 150 to $200 \mathrm{ft}$ upstream from the bridge (cross sections 1378-1402). The channel sides were not modified. Actual dredging would probably not create the uniform channel bottom depicted in the models. A comparison between the initial channel geometry and the hypothetical geometry is shown in figure 6, and a comparison of channelbed elevations is shown in figure 8. In the figures presented, these scenarios are represented as "Dredged."

\section{MD_SWMS Construction}

Multi-dimensional hydrodynamic models provide a physically based method for simulating hydraulic characteristics in complex flow environments for a range of discharges. For this investigation, the MD_SWMS version 2.3.5b, (McDonald and others, 2005), which incorporates the Flow and Sediment Transport and Morphological Evolution of Channels (FaSTMECH) 2- and 2.5-dimensional flow models (Nelson and others, 2003), was used. MD_SWMS is a graphical user interface for applying the FaSTMECH model that allows for, among other things, editing and visualizing of model input data, examining model output, and both visual and statistical evaluation of observed and predicted parameters (McDonald and others, 2005). FaSTMECH is a finite-difference, steadystate surface-water computer modeling system that simulates vertically averaged two-dimensional streamflow velocities on

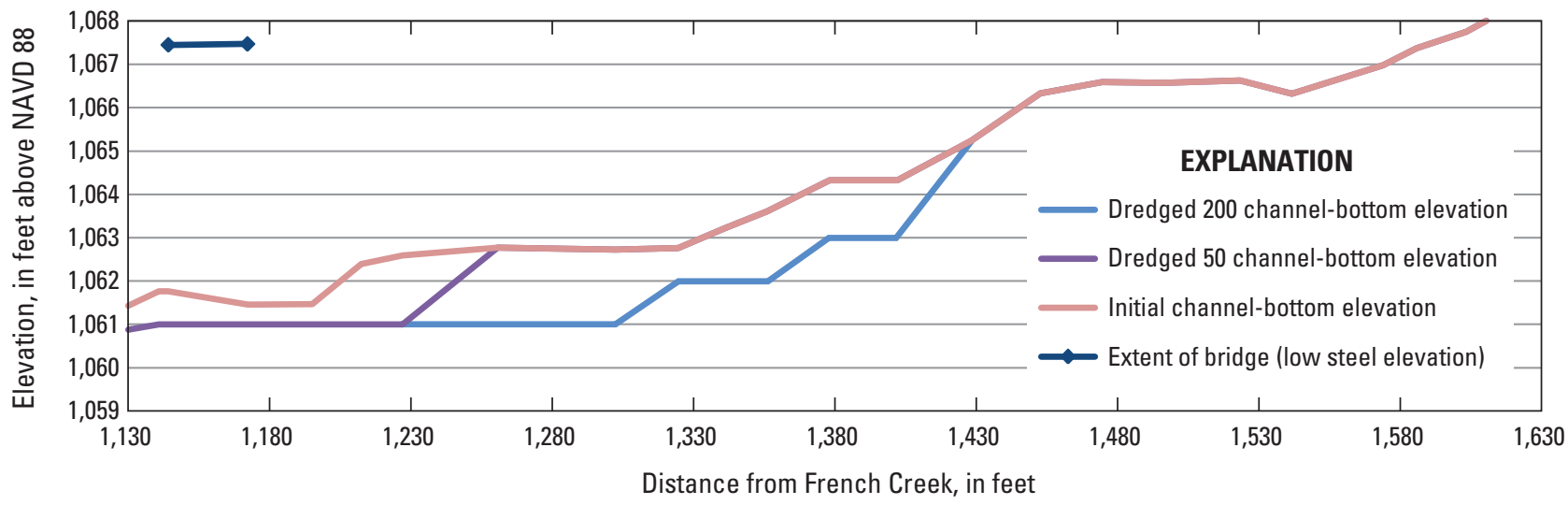

Figure 8. Elevations of the channel bed, Wymans Run, Crawford County, Pa., for the initial channel and the two dredged channel geometries as depicted in the Hydraulic Engineering Centers River Analysis System (HEC-RAS). 
the basis of input data and boundary conditions. Input data include surface topography (stream and overbank crosssection profiles), streamflow, water-surface elevation at the downstream boundary, and surface-material roughness entered as non-dimensional drag coefficients. FaSTMECH outputs shear-stress values from the two-dimensional velocity solution (Kenney, 2005). Model output from MD_SWMS was exported as point coverages and imported into ArcMap. For display purposes, the point coverages were interpolated using the inverse distance weighting (IDW) ArcMap algorithms. This modeling system has been used in a number of alluvial environments to predict hydraulic and sediment transport characteristics (Kenney, 2005; Barton and others, 2005).

\section{MD_SWMS Bathymetry}

The bathymetry data for use within MD_SWMS were imported from HEC-RAS. The bridge decking was not modeled within FaSTMECH because it cannot be supported within the computational grid. This was not a problem because the HEC-RAS simulations showed the decking was not a factor for streamflow simulations at the flows modeled because the water never reached the low steel elevation. The HECRAS cross sections representing the bridge were modified to simulate the bridge geometry. This was accomplished for all model geometries. MD_SWMS interpolates a continuous surface from the input topography with a triangulated irregular network (TIN) for the grid-defined model boundary.

\section{MD_SWMS Computational Grid and Boundary Conditions}

The computational grid used in MD_SWMS is a curvilinear orthogonal coordinate system with a user-defined centerline. The grid centerline is defined interactively to approximate the mean flow streamline of the modeling reach (Nelson and others, 2003). The model boundary is defined by the creation of a curvilinear grid in which the number of points along the stream length (streamwise) and the number of points across the stream (cross stream) are defined by the user. The computational grid used to model Wymans Run was approximately $1,312 \mathrm{ft}$ in length along the centerline with 801 streamwise nodes and $131 \mathrm{ft}$ wide with 80 cross-stream nodes. The cell sizes vary with a curvilinear grid, but a $1.64 \times 1.64 \mathrm{ft}$ grid was created along the centerline. The model input water surface at the downstream boundary was determined using the HEC-RAS simulations for the same channel and discharge conditions. In order to represent lateral momentum exchange resulting from turbulence or other variability not generated at the bed, FaSTMECH incorporates a lateral eddy viscosity (LEV) (Nelson and others, 2003), which was set to 0.05 for all simulations. The following equation can be used to compute the initial lateral eddy viscosity:

$$
L E V=.01 * \operatorname{avg}(u) * \operatorname{avg}(D),
$$

where
$L E V \quad$ is the lateral eddy-viscosity coefficient, in meters per second;
$\operatorname{Avg} u \quad$ is the average channel velocity, in meters per second; and
$\operatorname{Avg} D \quad$ is the mean depth of flow, in meters.

\section{Model Calibration-Drag Coefficient}

Model calibration consists of adjusting certain parameters in the model so the model output matches observations. In this study, the observations consisted of high-water marks for the June 2008 peak streamflow. The dimensionless drag coefficient, which represents the flow resistance in a channel, is one parameter that can be adjusted to calibrate the FaSTMECH model. The equation used by FaSTMECH for the determination of drag coefficient is

$$
\begin{gathered}
\text { Drag coefficient }=\text { coefficient } \\
* \text { depth } * \text { grainsize }(\text { D50) }
\end{gathered}
$$

where

$$
\begin{gathered}
\text { coefficient } \\
\text { is a constant adjustment multiplier; } \\
\text { is the depth of water, in meters; and } \\
\text { grainsize (D50) is the particle-size index, }
\end{gathered}
$$

where

(D50) is a particle size in millimeters for which 50 percent of the material is finer.

For equation 2, grainsize (D50) is expressed in meters.

Using estimated flow depths for the simulated June 2008 peak streamflow (with a constant drag coefficient throughout the channel) and D50 determined from field-sediment surveys, the dimensionless drag coefficient was initially calculated within MD_SWMS. To assign sediment sizes for the initial drag coefficient determination, the cross sections where sediment surveys were conducted were assigned the previously determined D50 value. The entire section downstream from the bridge was assigned the D50 determined at cross sections 1098 and 654. The bridge section was assigned the average of the D50 at the cross sections directly upstream and downstream from the bridge. The reach upstream from the bridge (cross sections 1175 to 1495) was assigned the D50 from cross sections 1357 and 1495 to 1629 ; the coefficient was assigned from cross section 1599. Determining the areas where sediment size values would be assigned was accomplished during the calibration process; an iterative process was used by assigning the sediment sizes to a range of cross sections, computing a water-surface elevation, comparing the surveyed high-water marks and the computed water-surface elevation, and then adjusting the range to better match the high-water marks. For cross sections 1261 to 1495 , the D50 was increased $0.018 \mathrm{~m}$ in order to increase the drag coefficient because the difference between the water-surface elevation and high-water 
marks was large using the computed D50. The input of sediment sizes into the FaSTMECH model resulted in variable drag coefficients throughout the channel based upon depth and sediment size.

The initial drag coefficients were then adjusted by a constant factor so the water level was comparable to the observed high-water marks. A coefficient of 0.9 was used for all simulations. On the basis of this drag coefficient "map" (fig. 9A), generalized regions of drag coefficients were developed (fig. 9B-D) and used in the model runs.

\section{Simulation Results}

HEC-RAS was used to estimate the peak streamflow for the June 2008 event that was simulated with FaSTMECH. Simulated water-surface elevations, velocity, and computed shear-stress values were obtained from FaSTMECH. Results are given for the initial channel geometry and the hypothetical bridge and channel geometry changes. Water-surface elevation results and boundary shear-stress distribution are given only for the highest streamflow simulated because these results are considered the most relevant.

\section{HEC-RAS Model Results}

HEC-RAS simulations were run using the steady-flow analysis routine with a normal depth and slope downstream boundary condition of $0.01 \mathrm{ft} / \mathrm{ft}$. In order to estimate streamflow for the June 2008 event, Manning's $n$ values were estimated using sediment-survey data and entered into the HEC-RAS model. Streamflow was adjusted until the watersurface elevation reasonably matched the surveyed high-water marks (fig 10). Matching the simulated water-surface elevations to surveyed high-water marks upstream from the bridge produced an estimated streamflow for the June 2008 event of $1,000 \mathrm{ft}^{3} / \mathrm{s}$. For cross sections 1378 to 1496 , the initial watersurface elevation simulation did not reasonably match the surveyed high-water marks. Because of the modest curvature in this section, a reasonable increase in Manning's $n$ from the straight-channel-section values would be 30 percent (Chow, 1959; Arcement and Schneider, 1984) and would result in a Manning's $n$ value of 0.065 . Even with this adjustment, the water-surface elevation did not match the high-water marks observed at these cross sections; the average difference between observed and simulated water-surface elevations for this section is $0.93 \mathrm{ft}$. Although the HEC-RAS water-surface elevation generally matches the upstream marks, the downstream high-water mark on the CSG was more than $1 \mathrm{ft}$ higher than that calculated by the model. This could be caused by turbulence downstream from the bridge, causing an artificially high mark in the CSG.

\section{FaSTMECH Model Results-Water-Surface Elevations}

Simulated water-surface elevations for the entire Wymans Run study reach for the June 2008 storm are shown in figure 11 along with the elevation of the top of the left bank. In the vicinity of the study reach, the right bank is higher than the left and not subject to overflow. High-water marks and photographs taken during the June 2008 storm show water flowing out of the channel on the left bank about 1,418 to $1,475 \mathrm{ft}$ upstream from French Creek. The FaSTMECH model was calibrated to match these observations at a streamflow of $1,000 \mathrm{ft}^{3} / \mathrm{s}$. The simulated water-surface elevations for the hypothetical bridge and channel geometries are shown in figure 12. The water-surface elevation generated with the expanded bridge geometry shows the largest water-surface elevation difference to be directly upstream from the bridge, a decrease of $0.7 \mathrm{ft}$. The simulations of a deeper channel from the bridge to $200 \mathrm{ft}$ upstream indicate a decrease in the watersurface elevation at 1,402 ft from French Creek (about $225 \mathrm{ft}$ upstream from the bridge where the left bank was overtopped) of about $1.0 \mathrm{ft}$; farther upstream, the dredging rapidly loses effectiveness in lowering the water-surface elevation from the initial simulation. Simulations of the expanded channel configuration resulted in a lower the water-surface elevation farther upstream from the dredging, which could prevent the water from overtopping the left channel bank at these points during a storm of similar size. The simulated water-surface elevation at selected cross sections for the initial geometry and the watersurface elevation difference for the hypothetical geometries at a streamflow of $1,000 \mathrm{ft}^{3} / \mathrm{s}$ are listed in table 2 . Channel cross sections not shown in figure 12 were not affected by the hypothetical channel changes, and the simulated water-surface elevation was unchanged.

\section{FaSTMECH Model Results-Velocity Distribution}

Stream velocity can show the potential for sediment deposition. Two sediment-movement diagrams, the Hjulström diagram (Hjulström, 1939) and the Sundborg diagram (Sundborg, 1956) are generated using stream velocity and sediment size to graphically depict regions of sediment erosion, transport, and deposition. A variation of the original Hjulström diagram from Karrok (2009) is shown in figure 13.

The lines shown in figure 13 could be shown as broad regions of uncertainty because there are many variations of this diagram in the literature with broad ranges of deposition velocity (Hjulström, 1939; Sundborg, 1956; Karrok, 2009). In light of this uncertainty, the analysis of sediment movement that was completed in this study with shear stress does not use velocity as a factor. The conclusion that can be reached from the literature is that the velocity required to pick up bed material is more than that required to keep the material moving downstream. As might be expected, the largest particles will deposit first as the velocity in the stream decreases. The 

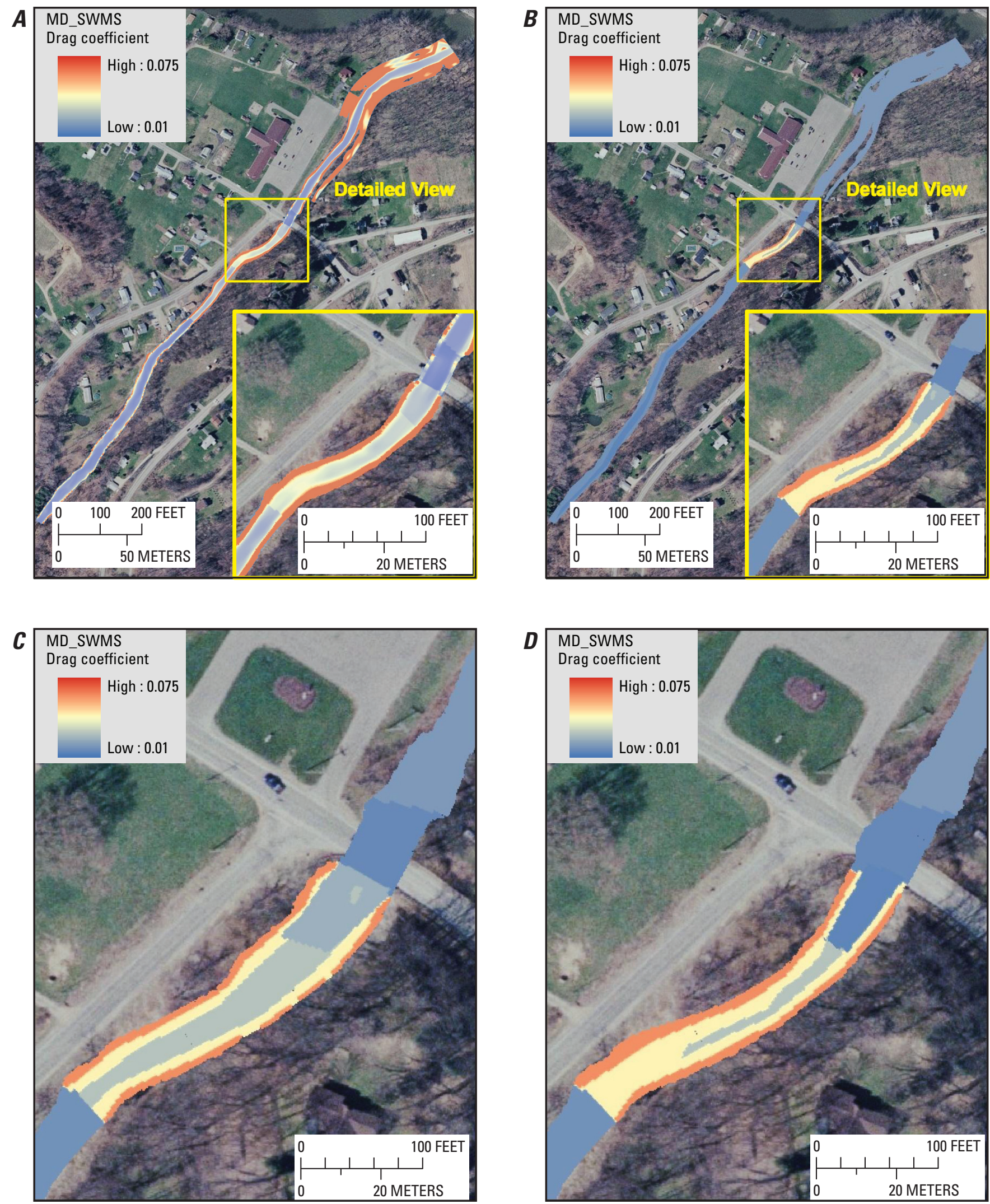

Figure 9. Multi-Dimensional Surface-Water Modeling System (MD_SWMS) drag coefficients determined for the Wymans Run study reach, Crawford County, $\mathrm{Pa} .,(A)$ using sediment sizes determined from field surveys and depth determined from a model run at a streamflow of 1,000 cubic feet per second, $(B)$ actual drag coefficients used for the initial channel geometry, $(C)$ close up of drag coefficients used in the widened channel geometry, and $(D)$ close up of drag coefficients used in the dredged 50 channel geometry. 


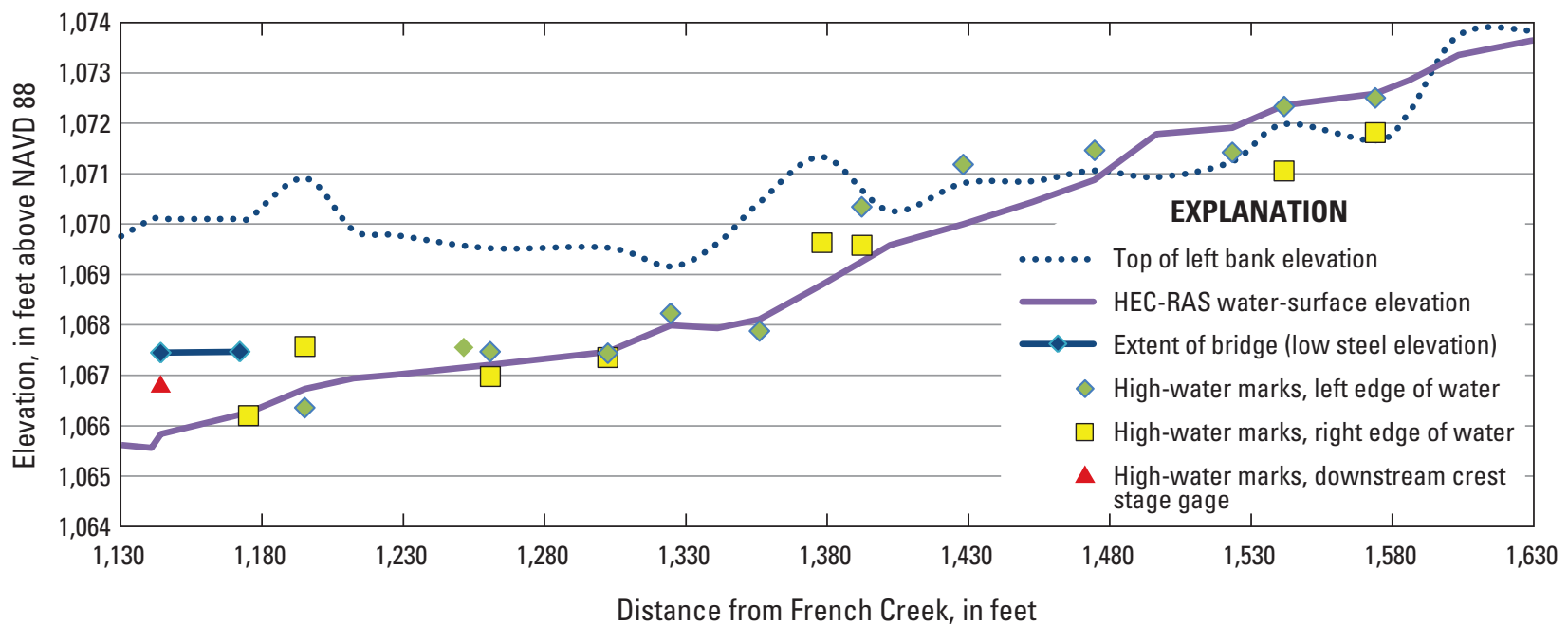

Figure 10. Surveyed high-water marks after the June 2008 storm, and the Multi-Dimensional Surface-Water Modeling System (MD_SWMS) simulated initial water-surface elevation and various elevations for a streamflow of 1,000 cubic feet per second, Wymans Run study reach, Crawford County, Pa.

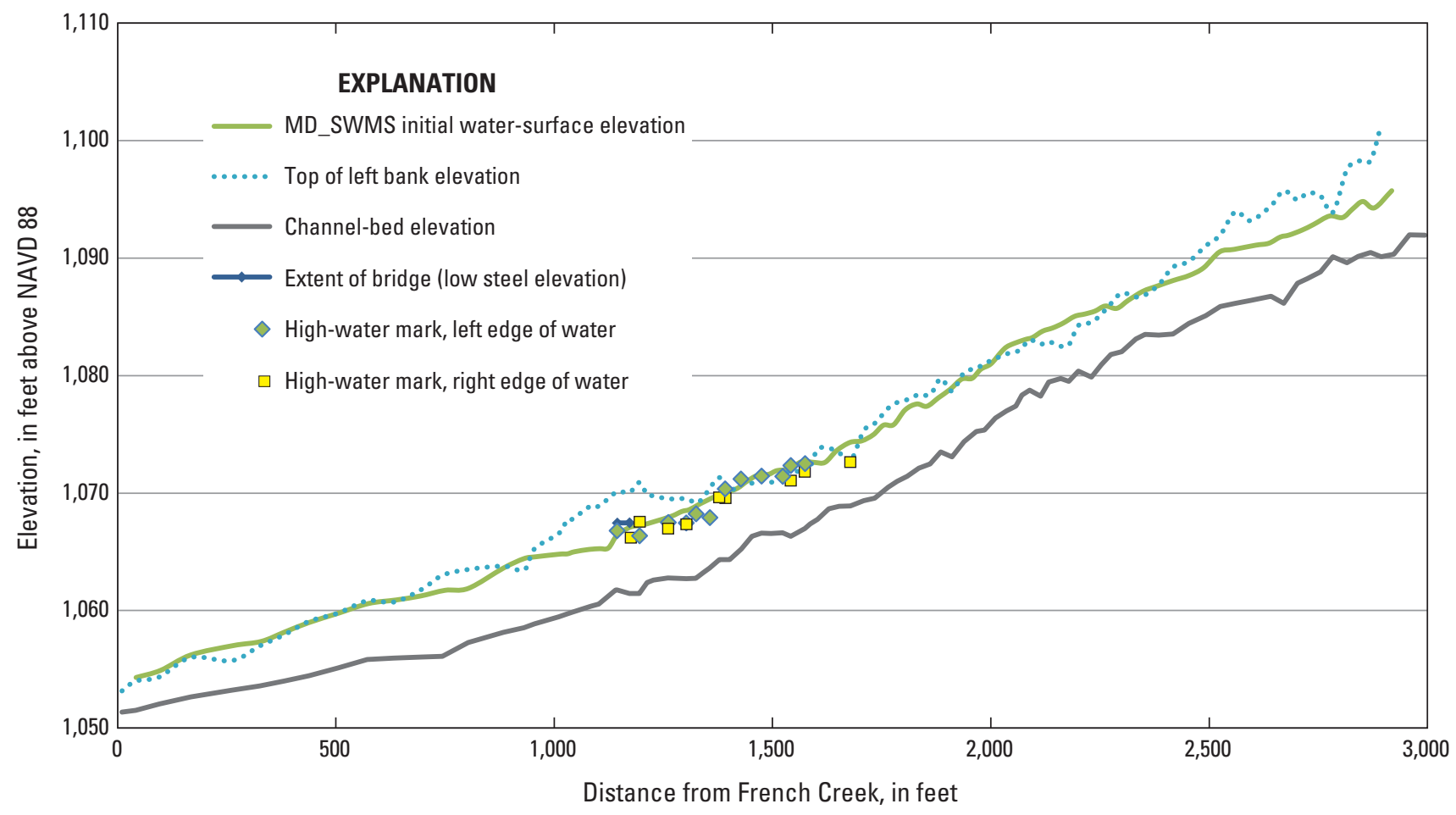

Figure 11. Surveyed high-water marks after the June 2008 storm, the simulated Hydrologic Engineering Centers River Analysis System (HEC-RAS) water-surface elevation for a streamflow of 1,000 cubic feet per second, and elevation of the left bank, Wymans Run study reach, Crawford County, Pa. 


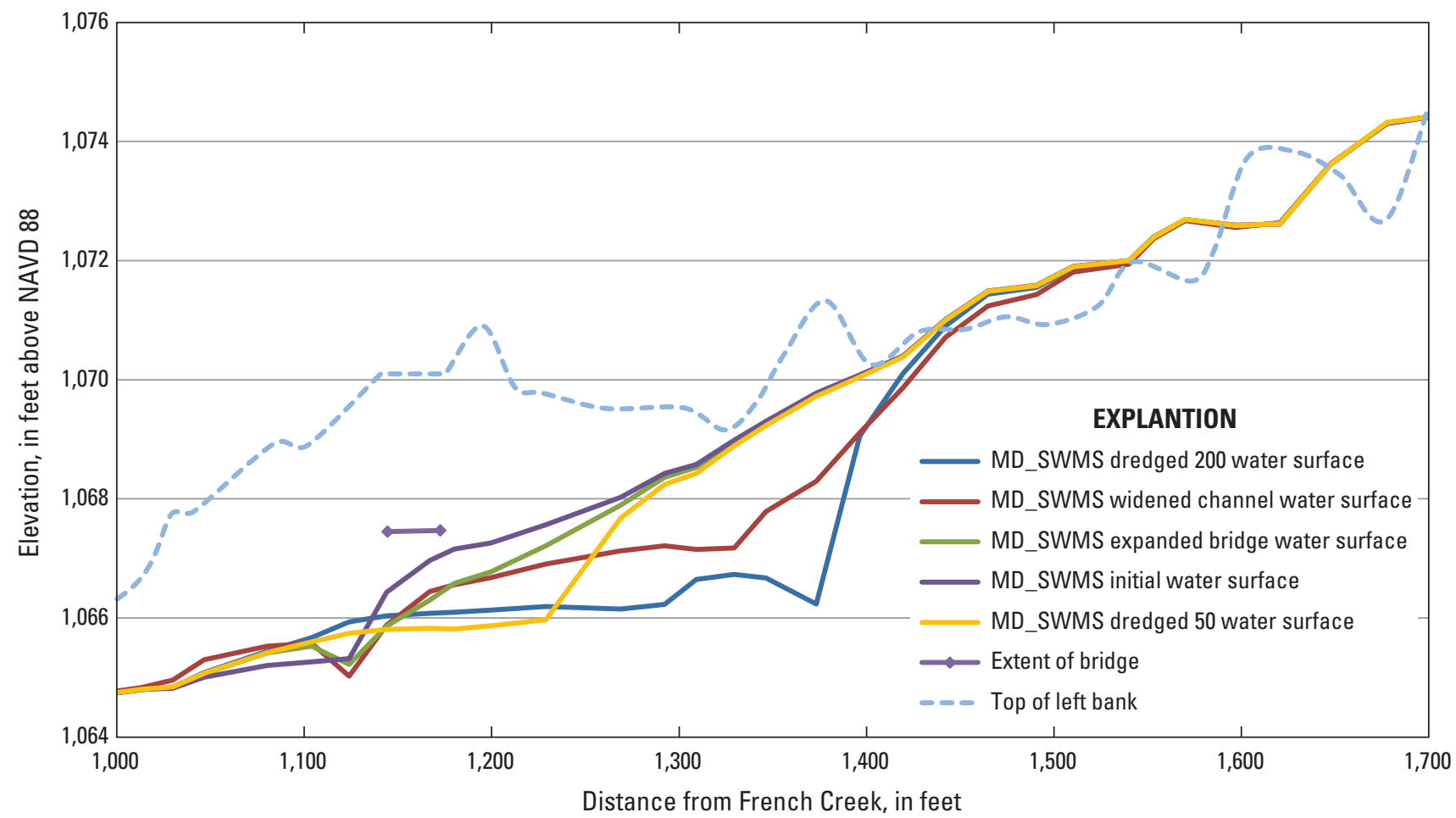

Figure 12. Flow and Sediment Transport and Morphological Evolution of Channels (FaSTMECH) model simulated initial water-surface elevation and the simulated water-surface elevations for hypothetical geometries for a streamflow of 1,000 cubic feet per second, Wymans Run study area, Crawford County, Pa.

Table 2. Flow and Sediment Transport and Morphological Evolution of Channels (FaSTMECH) model simulated water-surface elevations for the initial channel geometry and elevation differences between the initial geometry and the hypothetical channel geometries for a streamflow of 1,000 cubic feet per second at selected cross sections, Wymans Run study area, Crawford County, Pa.

[Elevations are referenced to the North American Vertical Datum of 1988. ft, feet]

\begin{tabular}{|c|c|c|c|c|c|}
\hline $\begin{array}{c}\text { Cross-section designation } \\
\text { (distance above French } \\
\text { Creek (ft)) }\end{array}$ & $\begin{array}{l}\text { Initial channel } \\
\text { geometry }\end{array}$ & \multicolumn{4}{|c|}{ Elevation difference ( $\mathrm{ft}$ ) } \\
\hline 1,141 & $1,065.32$ & -0.10 & -0.29 & 0.40 & 0.61 \\
\hline Bridge $(1,155)$ & $1,066.43$ & -0.57 & -0.55 & -0.65 & -0.39 \\
\hline 1,212 & $1,067.56$ & -0.35 & -0.65 & -1.70 & -1.37 \\
\hline 1,261 & $1,068.03$ & -0.14 & -0.90 & -0.38 & -1.88 \\
\hline 1,356 & $1,068.58$ & -0.05 & -1.43 & -0.17 & -1.94 \\
\hline 1,356 & $1,069.30$ & -0.03 & -1.51 & -0.08 & -2.59 \\
\hline 1,496 & $1,071.58$ & 0.00 & -0.15 & 0.00 & -0.03 \\
\hline 1,542 & $1,072.00$ & 0.00 & -0.06 & 0.00 & 0.00 \\
\hline
\end{tabular}




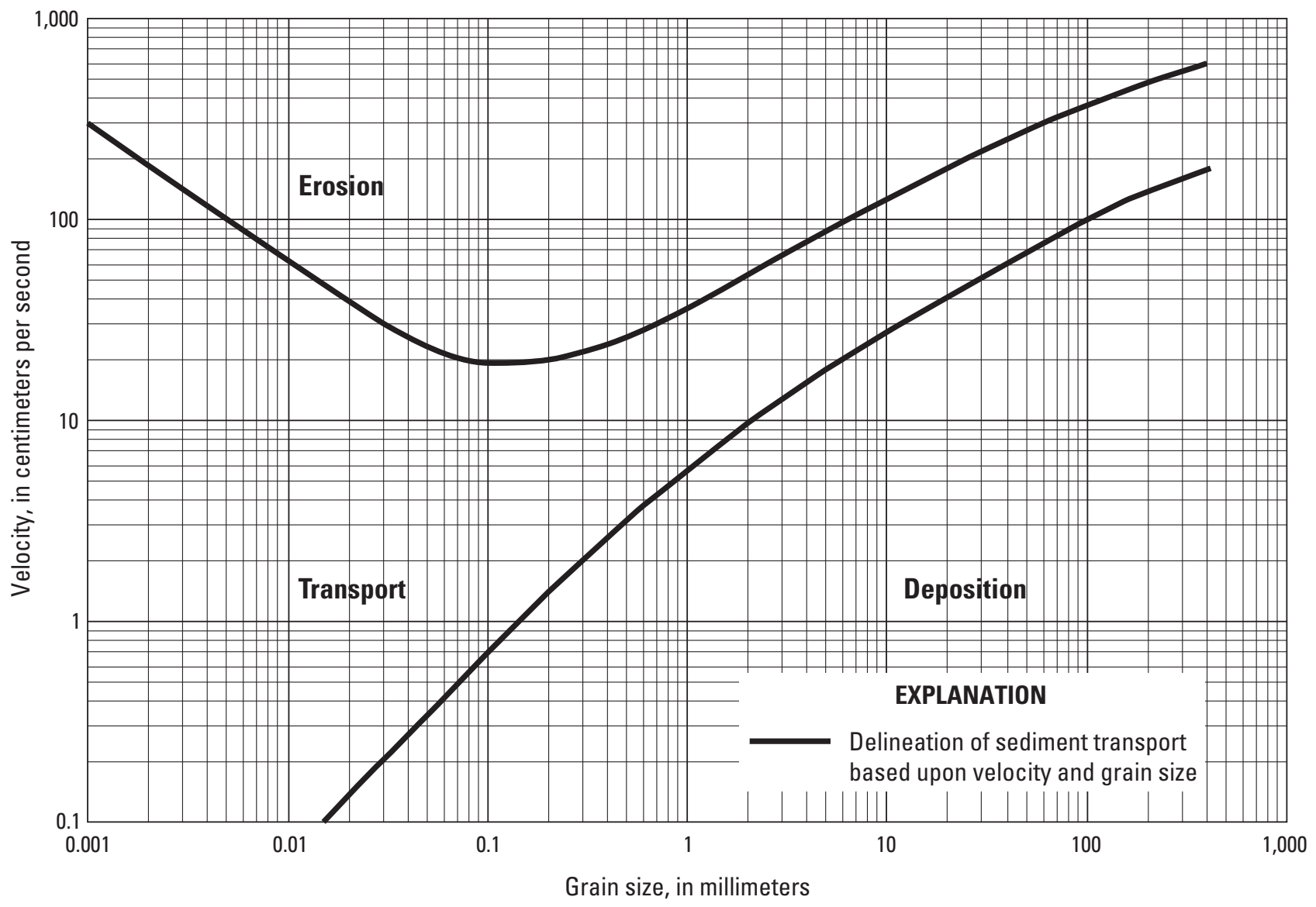

Figure 13. Variation of the Hjulström diagram showing streamflow in relation to grain size (Modified from Karrok, 2009).

computed velocity distributions can show where the sediment may be deposited by looking at areas of different velocity magnitudes in the stream, not necessarily the absolute velocity. Areas of comparatively slower velocities in the stream have a higher potential for deposition than those in the areas with faster velocities. Velocities for a streamflow of $1,000 \mathrm{ft}^{3} / \mathrm{s}$ for the initial and hypothetical stream geometries are described in the sections below.

\section{Velocity Distribution for Initial Channel Geometry}

At a streamflow of $1,000 \mathrm{ft}^{3} / \mathrm{s}$, the main in-channel velocity is such that all variations of the Hjulström diagrams indicate the water is moving fast enough that sediment is being transported but is not being deposited during the time period when that flow (or higher) is occurring (fig. 14). Simulated flows show that sediment would not build up underneath the bridge during the peak flow, thus the buildup seen after a storm is not occurring until the recession (after the flooding potential). As a result, the sediment in the channel does not appear to be an additional factor in flooding. Focusing on the reach immediately upstream from the bridge, the velocity is lower, compared to that of the surrounding area. This could indicate areas where sediment will preferentially deposit, which are consistent with the sediment deposition observed after the June 2008 storm (fig 6).

\section{Velocity Distribution for Hypothetical Channel Geometries}

A comparison of velocity differences between the initial geometry and the hypothetical geometries provides an indication of areas within the study reach where velocities change because of the channel modifications. These differences may indicate possible streambed changes, but the actual sedimentation patterns would not be evident. Velocity distributions for the hypothetical channel geometries at a streamflow of $1,000 \mathrm{ft}^{3} / \mathrm{s}$ are provided in figure 15 . Results of simulations using a streamflow of $1,000 \mathrm{ft}^{3} / \mathrm{s}$ at the expanded bridge (fig. 15A) and at the dredged channel $50 \mathrm{ft}$ upstream from the bridge (fig. 15C) show that the velocity at the bridge is fast enough to transport most sediment sizes. Thus, sediment would not be deposited and affect conveyance during the flows greater than or equal to a streamflow of $1,000 \mathrm{ft}^{3} / \mathrm{s}$. A 


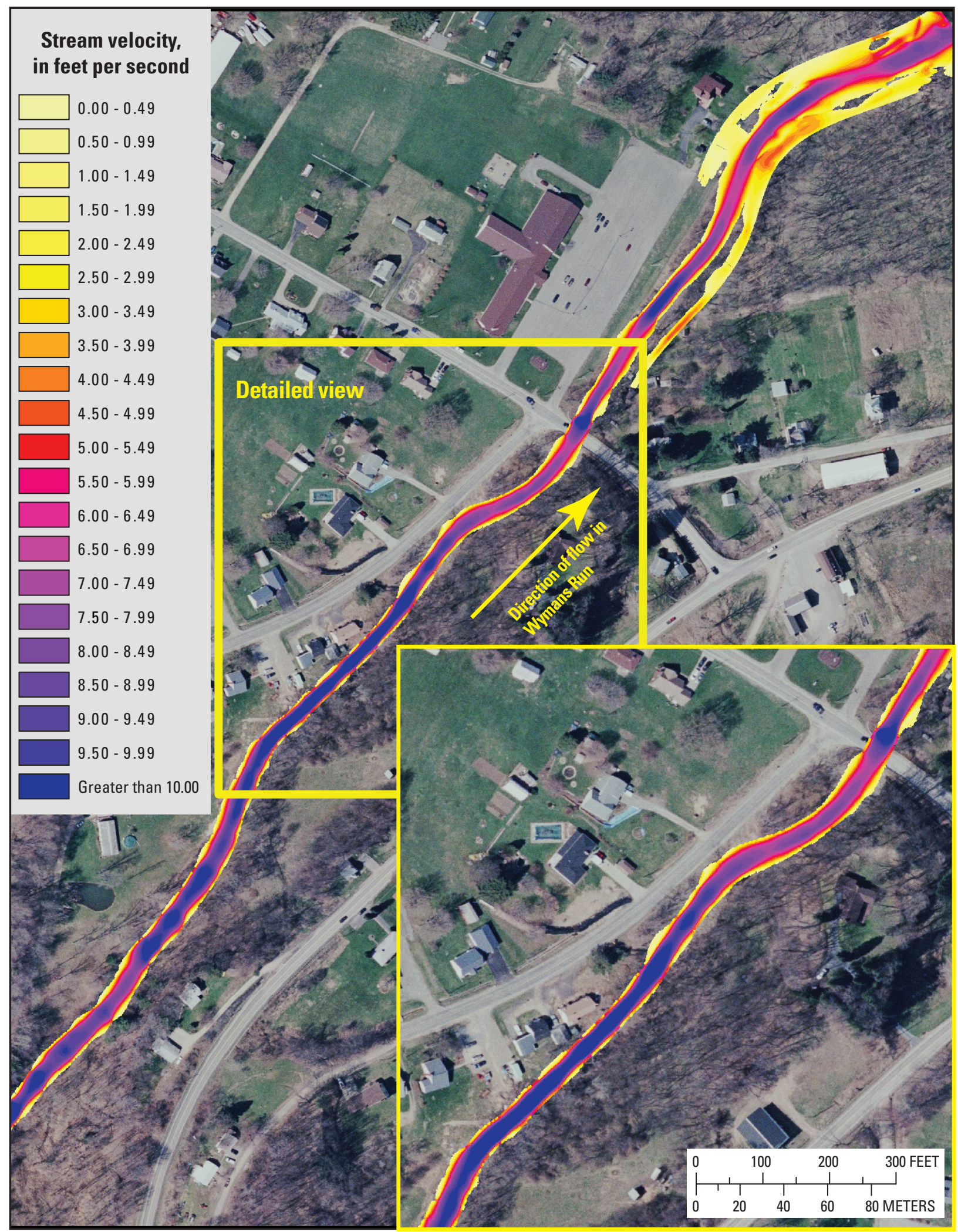

Figure 14. Flow and Sediment Transport and Morphological Evolution of Channels (FaSTMECH) model simulated stream velocities for a streamflow of $1,000 \mathrm{ft}^{3} / \mathrm{s}$ for the initial channel geometry, Wymans Run study reach, Crawford County, Pa. 

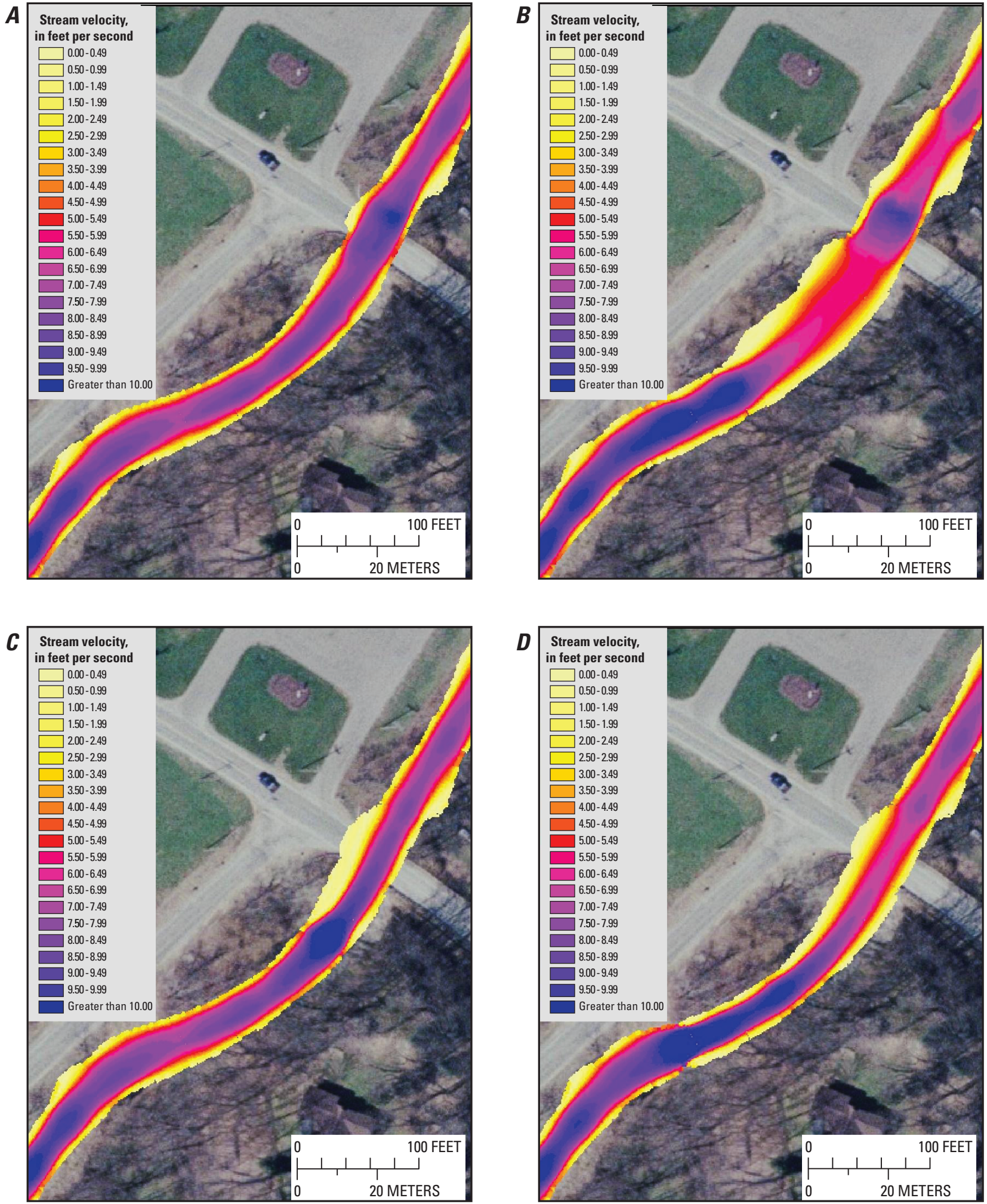

Figure 15. Flow and Sediment Transport and Morphological Evolution of Channels (FaSTMECH) model simulated velocity for $(A)$ the expanded bridge, $(B)$ the widened channel, $(C)$ the stream channel dredged 50 feet upstream, and $(D)$ the stream channel dredged 200 feet upstream for a streamflow of 1,000 cubic feet per second, Wymans Run study reach, Crawford County, Pa. 
comparison of the results of simulations of the initial channel geometry with the results for the hypothetical expanded bridge geometry indicates that the expanded bridge geometry allows water to move at a higher velocity upstream from the bridge; this may lead to flushing of sediment downstream and under the bridge. The widened channel geometry generates much slower velocities in the widened area as a result of the increased channel area. The stream channel dredged $50 \mathrm{ft}$ upstream from the bridge results in faster velocities in the middle of the channel than those in the expanded bridge scenario upstream from the bridge. However, the velocity on the left side of the channel appears to be about $3 \mathrm{ft} / \mathrm{s}$ slower directly upstream from the bridge, implying sediment may still be deposited on that side. The scenario of the stream channel dredged $200 \mathrm{ft}$ upstream from the bridge shows water slowing down in the dredged region, compared to the channel without dredging, indicating the potential for sediment deposition. This is consistent with the concept of a sediment trap that would most likely be formed by the dredged channel until the channel slope is returned to the slope of the upstream reach. These simulations do not produce an estimate of time scale for sediment deposition, only the potential for deposition. The velocity values for all scenarios at selected cross sections are listed in table 3 .

\section{FaSTMECH Model Results-Shear-Stress Distribution}

Kenney (2005) describes a method of graphically representing shear-stress distribution in a stream in terms of the size of material that may be transported. Boundary shear stress can be used to predict when different sizes of bed material begin to move in the water column by assuming motion is initiated when the predicted boundary stress exceeds the critical shear stress for a particle class size. Sediment class, sediment size in metric and English units (Sturm 2001), Shields parameter, and the range of values for critical shear stress for the sediment class (Berenbrock and Tranmer, 2008) are listed in table 4.

Channel boundary shear stress as predicted by FaST$\mathrm{MECH}$ is calculated using the following equation

$$
\tau b=\rho C_{d}(u 2+v 2),
$$

where

$\tau b \quad$ is the boundary shear stress, in pounds per square foot $\left(\mathrm{lb} / \mathrm{ft}^{2}\right)$;

$\rho \quad$ is the fluid density, in pounds per cubic foot $\left(\mathrm{lb} / \mathrm{ft}^{3}\right)$;

$C_{d} \quad$ is the nondimensional drag coefficient;

$u$ is the vertically averaged $\mathrm{x}$ component of velocity, in $\mathrm{ft} / \mathrm{s}$; and

$v \quad$ is the vertically averaged y component of velocity, in ft/s.
Critical shear stress for each sediment class is calculated using the equation

$$
\tau_{b c}=\tau_{b c}^{*}\left(\left(\gamma_{s} / \gamma\right)-1\right) \gamma d,
$$

where

$$
\begin{array}{cl}
\tau_{b c} & \text { is the dimensional critical boundary shear } \\
& \text { stress, in lbs/ } \mathrm{ft}^{2} ; \\
\tau_{b c}^{*} & \text { is the non-dimensional critical boundary } \\
& \text { shear stress; } \\
\gamma_{s} & \text { is the specific weight of sediment, in } \mathrm{lbs} / \mathrm{ft}^{3} ; \\
\gamma & \text { is the specific weight of water, in } \mathrm{lbs} / \mathrm{ft}^{3} \text {; and } \\
d & \text { is grain size, in feet. }
\end{array}
$$

Non-dimensional critical shear-stress values for the grain sizes were obtained from the Shields diagram (see Sturm (2001) for a comprehensive explanation of the Shields diagram) after first computing non-dimensional sediment grain sizes using the equation

$$
d^{*}=\frac{\left(\left(\frac{\gamma_{S}}{\gamma}\right)-1\right) g d^{\wedge} 3}{v^{\wedge} 2},
$$

where

$$
\begin{array}{ll}
d^{*} & \text { is the nondimensional grain size; } \\
\gamma_{S} & \text { is the specific weight of sediment, in pounds } \\
& \text { per cubic foot; }
\end{array}
$$

To aid in the evaluation and presentation of predicted boundary shear-stress values, Kenney's plots were constructed with colors developed from empirical critical shear-stress values of specific grain sizes. Kenney (2005) presents only critical shear-stress values up to the size of very coarse gravel (32-64 $\mathrm{mm}$ or 1.3-2.5 in.). In a similar study, Berenbrock and Tranmer (2008) give critical shear-stress values up to the large cobble size (128-256 $\mathrm{mm}$ or 5-10 in.). The sediment grade scale (Sturm, 2001) is presented in table 4 for reference. It is important to emphasize that this analysis determines whether or not a given grain size is likely to become mobile but does not provide information regarding scour, deposition, or the volume of material that might be transported.

\section{Shear-Stress Distribution for Existing Channel Geometry}

The predicted boundary shear-stress values for the June 2008 peak streamflow of $1,000 \mathrm{ft}^{3} / \mathrm{s}$ were assigned a color on the basis of the maximum grain size available to be 
Table 3. Flow and Sediment Transport and Morphological Evolution of Channels (FaSTMECH) model maximum simulated velocity for the initial and hypothetical channel geometries for a streamflow of 1,000 cubic feet per second at selected cross sections, Wymans Run, Crawford County, Pa.

[Velocity is in feet per second. $\mathrm{ft}$, feet]

\begin{tabular}{cccccc}
\hline \multirow{2}{*}{$\begin{array}{c}\text { Cross-section designation } \\
\text { (distance above French }\end{array}$} & Mrimum simulated velocity \\
\cline { 2 - 5 } Creek (ft)) & $\begin{array}{c}\text { Initial channel } \\
\text { geometry }\end{array}$ & $\begin{array}{c}\text { Expanded } \\
\text { bridge }\end{array}$ & $\begin{array}{c}\text { Widened } \\
\text { channel }\end{array}$ & Dredged 50 & Dredged 200 \\
\hline 1,102 & 12.4 & 9.8 & 8.8 & 8.1 & 6.8 \\
1,141 & 11.4 & 10.4 & 9.8 & 8.2 & 6.7 \\
Bridge (1,155) & 9.0 & 9.1 & 8.3 & 8.4 & 6.5 \\
1,175 & 8.0 & 8.9 & 7.0 & 8.7 & 6.7 \\
1,212 & 7.3 & 8.2 & 5.8 & 9.3 & 7.1 \\
1,261 & 7.9 & 8.6 & 6.0 & 11.8 & 8.2 \\
1,356 & 8.4 & 8.7 & 6.7 & 9.2 & 9.8 \\
1,356 & 8.4 & 8.5 & 10.4 & 8.6 & 10.3 \\
1,402 & 7.5 & 7.5 & 10.3 & 7.6 & 9.4 \\
1,459 & 8.1 & 8.1 & 10.4 & 8.3 & 8.8 \\
1,496 & 8.6 & 8.6 & 9.5 & 8.6 & 9.7 \\
\hline
\end{tabular}

Table 4. Sediment grade scale, Shields parameter, and critical shear-stress ranges for each sediment class.

[Grade scale from Strum (2001) Shields parameter and critical shield stress ranges from Berenbrock and Tranmer (2008). lbs/ft ${ }^{2}$, pounds per feet squared]

\begin{tabular}{lllcl}
\hline \multicolumn{1}{c}{$\begin{array}{c}\text { Sediment } \\
\text { material }\end{array}$} & $\begin{array}{c}\text { Grain diameter } \\
\text { (millimeters) }\end{array}$ & $\begin{array}{c}\text { Grain diameter } \\
\text { (inches) }\end{array}$ & $\begin{array}{c}\text { Shields } \\
\text { parameter } \\
\text { (dimensionless) }\end{array}$ & $\begin{array}{c}\text { Range of critical } \\
\text { shear stress } \\
\text { (lbs/ft') }\end{array}$ \\
\hline Very fine sand & $0.0622-0.125$ & $0.0025-0.0049$ & $0.109-0.072$ & $0.0029-0.0038$ \\
Fine sand & $0.125-0.250$ & $0.0049-0.0098$ & $0.072-0.048$ & $0.0038-0.0042$ \\
Medium sand & $0.25-0.50$ & $0.0098-0.0197$ & $0.048-0.033$ & $0.0042-0.0054$ \\
Coarse sand & $0.5-1.0$ & $0.020-0.039$ & $0.033-0.029$ & $0.0118-0.0304$ \\
Very coarse sand & $1-2$ & $0.039-0.079$ & $0.029-0.039$ & $0.0304-0.0608$ \\
Very fine gravel & $2-4$ & $0.079-0.157$ & $0.039-0.042$ & $0.0608-0.1216$ \\
Fine gravel & $4-8$ & $0.16-0.31$ & $0.042-0.044$ & $0.0608-0.1216$ \\
Medium gravel & $8-16$ & $0.31-0.63$ & $0.044-0.047$ & $0.1216-0.2432$ \\
Coarse gravel & $16-32$ & $0.63-1.26$ & $0.047-0.05$ & $0.2432-0.4865$ \\
Very coarse gravel & $32-64$ & $1.3-2.5$ & $0.05-0.052$ & $0.4865-0.9729$ \\
Small cobbles & $64-128$ & $2.5-5.0$ & $0.054-0.052$ & $0.9729-1.9458$ \\
Large cobbles & $128-256$ & $5.0-10.1$ & $0.054-0.054$ & $1.9458-3.8916$ \\
\hline
\end{tabular}


transported, based on the non-dimensional computed critical shear-stress values (fig. 16). At a streamflow of $1,000 \mathrm{ft}^{3} / \mathrm{s}$, the boundary shear stress in the stream is such that large cobbles (grain size of 5-10 inches) can be moved at most locations in the channel. One noticeable exception is directly upstream and downstream from the PA 285 bridge where the boundary shear stress is less than in the reaches farther upstream and downstream from the bridge. Velocity plots for the simulation (fig. 14 and table 3) also show that the area upstream from the bridge has slower average velocities than the surrounding areas. This confirms the observation that larger sediment deposited upstream from the bridge from prior storms will not necessarily wash out.

\section{Shear-Stress Distribution for Hypothetical Channel Geometries}

Shear-stress distributions of sand, gravel, and cobbles for the hypothetical channel geometries for a streamflow of $1,000 \mathrm{ft}^{3} / \mathrm{s}$ are shown in figure 17. For the expanded bridge geometry (fig. 17A), a noticeable difference is an increase in boundary shear stress directly upstream from the bridge, indicating an increased capability to move sediment, possibly under the bridge. Widening the channel upstream and downstream from the bridge (fig. 17B) causes a decrease in boundary shear stress (compared to the initial channel) throughout much of the widened reach. At a streamflow of $1,000 \mathrm{ft}^{3} / \mathrm{s}$, the dredged channel 50 and $200 \mathrm{ft}$ upstream from the bridge shows a decrease in boundary shear stress in the dredged area of the channel (fig. 17C, D). Larger sediment in these areas would not become mobile.

\section{Model Limitations}

Specific limitations of the constructed model restrict the extent of interpretations and results presented in this report. Valid interpretation of the results presented in this report requires a clear understanding of these limitations. The models used in this analysis should be considered not fully calibrated because field data, such as streamflow during the June 2008 storm and high-water marks downstream from the PA 285 bridge, were not available to verify the calibration. The most critical factor is the extreme variation in channel geometry from before the June 2008 rain event to after the event. The changes in the cross-sectional area at the upstream side of the bridge before and after the June 2008 storm are shown in figure 6A. The models are based on the surveyed geometry of the channel before the storm; however, there is no assurance that the geometry used represents the geometry at the time of the storm. The storm occurred over a few hours, and a streamflow measurement was not made. Streamflow was determined indirectly using surveyed cross sections, measured water-surface elevations, and selected Manning's $n$ values. For the scenarios that are described, the proposed bridge expansion, widened channel, and dredged channel geometries are hypothetical. At the time of this writing (2010), the plans for the PA 285 bridge have not been finalized and may not match the dimensions of the hypothetical bridge geometry that was used in this analysis. Many variables exist in the hypothetical dredged channel geometries such as how far upstream the dredging may go and how far across the channel will be dredged. Most importantly, the depth of the dredging will greatly affect both stream velocity and elevation in the stream channel.

The HEC-RAS model was run as a steady-state simulation although the extremely fast rise and fall of the stream would indicate the flow was unsteady. A temporary gage was installed at the site; however, the data were considered unreliable because the instrument was over-topped during the rain event, and the gage data were not used.

The bathymetry used for MD-SWMS is a combination of surveyed field data and LiDAR data that were processed for HEC-RAS using HEC-GeoRAS routines available in ArcGIS. Once the bathymetry was in HEC-RAS, interpolation routines were used, and the interpolated data were imported into MDSWMS. The use of LiDAR data and interpolated bathymetry could decrease the accuracy of the stream-channel elevations and affect the resulting water-surface elevations, shear stress, and velocity data.

\section{Summary and Conclusions}

A hydraulic model, U.S. Army Corps of Engineers onedimensional Hydrologic Engineering Centers River Analysis System (HEC-RAS) and a hydrodynamic model, Flow and Sediment Transport and Morphological Evolution of Channels (FaSTMECH), which is incorporated into the U.S. Geological Survey Multi-Dimensional Surface-Water Modeling System (MD_SWMS), were constructed and calibrated for a selected reach of Wymans Run in Cochranton Borough, Crawford County, Pa. Inputs for these models include field surveyed cross sections, sediment surveys, a digital elevation model developed from LiDAR data, and high-water cross-section data collected following a storm in June 2008.

After the models were calibrated using the channel conditions observed in 2007, scenarios were generated with hypothetical channel geometries, including an expansion of the existing PA 285 bridge, expansion of the channel upstream and downstream from the bridge, and dredging the channel 50 and $200 \mathrm{ft}$ upstream from the bridge. Frequent changes in the channel geometry created by storms made it difficult to establish a normal channel condition. The models produced values for boundary shear stress and velocity, which are indicators of sediment transport at the maximum streamflow estimated for a June 2008 rain event. The values of boundary shear stress produced by FaSTMECH for the simulated streamflow of $1,000 \mathrm{ft}^{3} / \mathrm{s}$ indicate that most sediment in the channel can be moved. The velocity during these conditions shows sediment is moving at the simulated flow of $1,000 \mathrm{ft}^{3} / \mathrm{s}$, thus the issue 


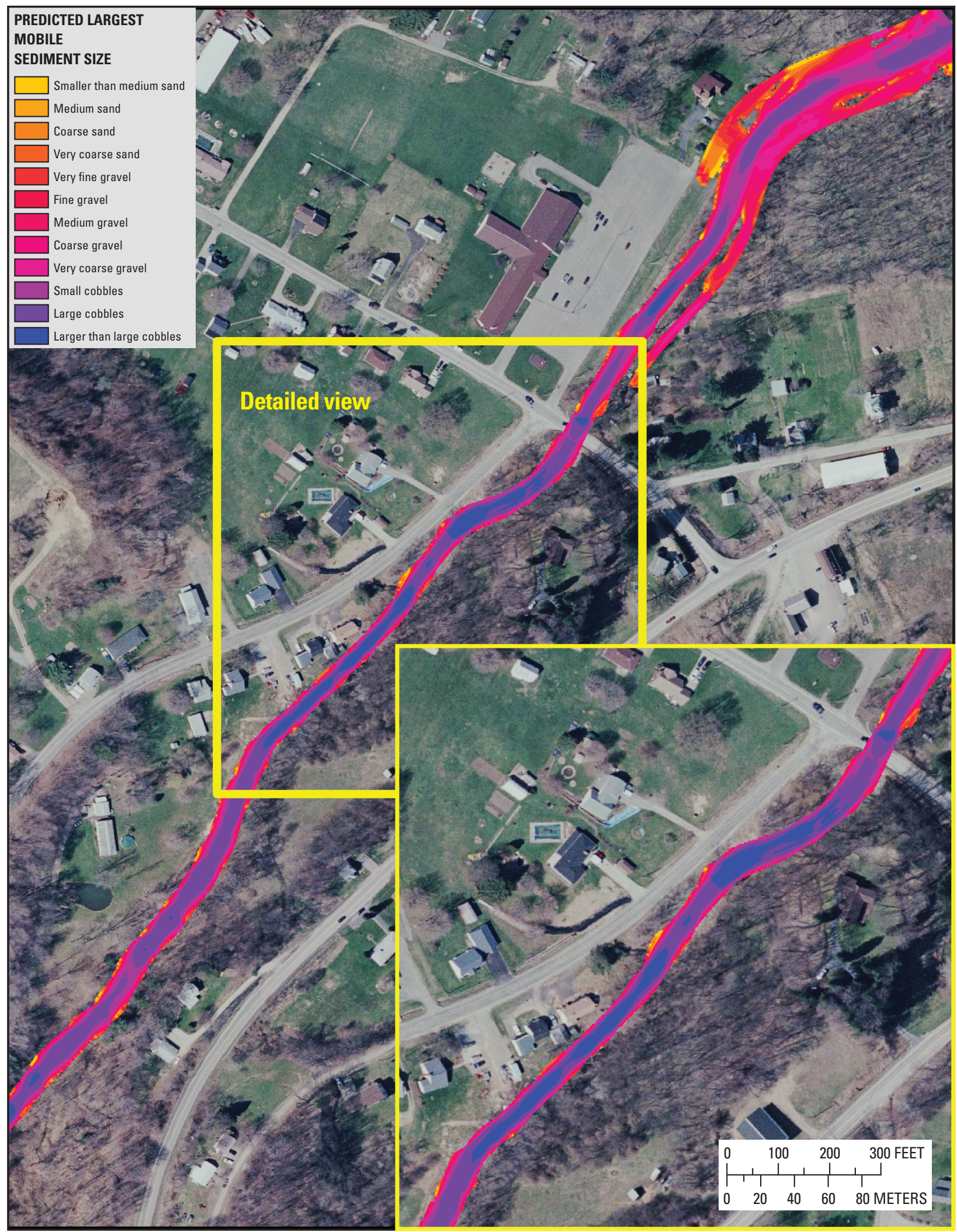

Figure 16. Flow and Sediment Transport and Morphological Evolution of Channels (FaSTMECH) model predicted largest mobile sediment size based upon critical boundary shear stress values for each sediment class at a streamflow of 1,000 cubic feet per second for the initial channel geometry, Wymans Run study reach, Crawford County, Pa. 

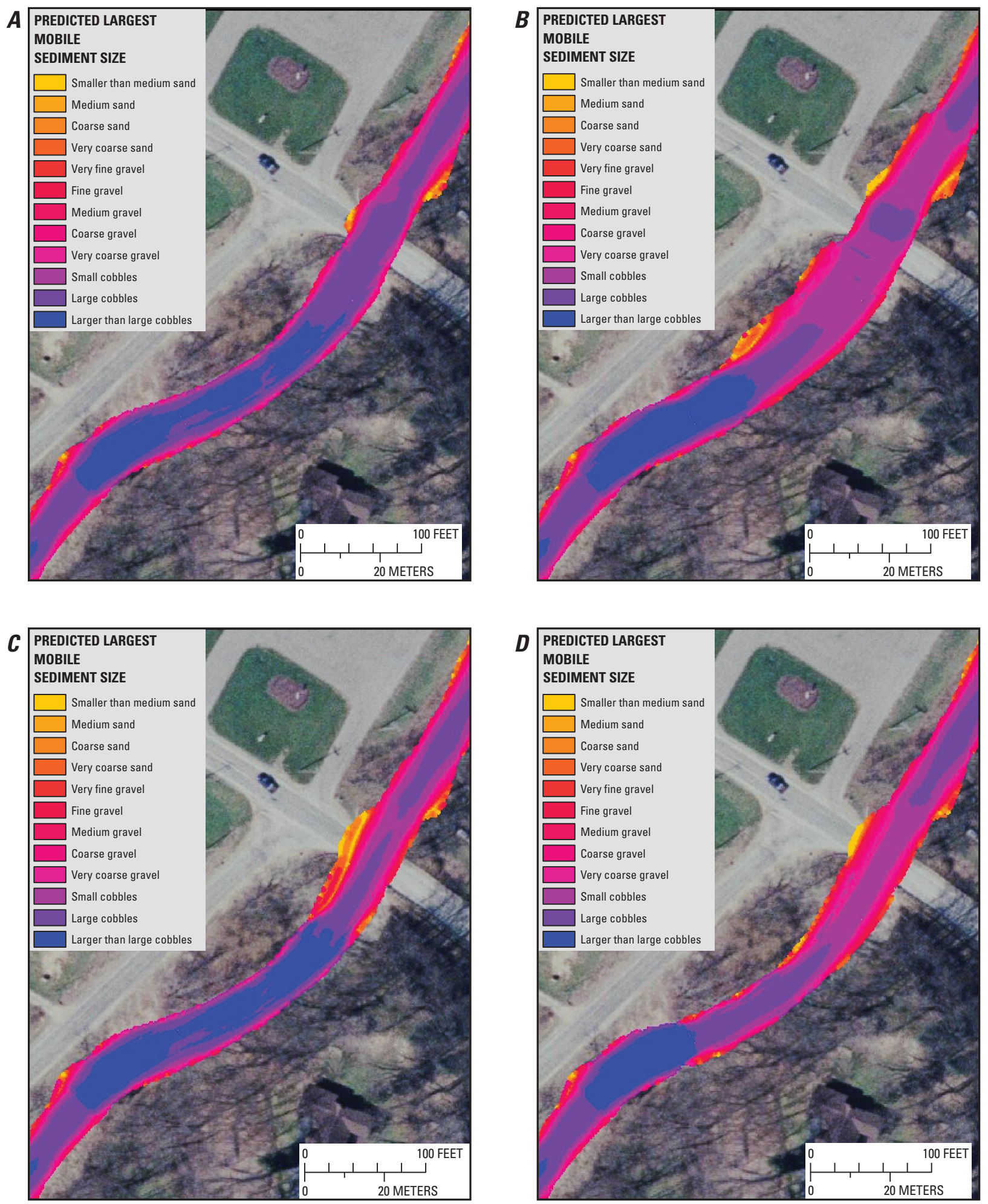

Figure 17. Flow and Sediment Transport and Morphological Evolution of Channels (FaSTMECH) model largest mobile sediment size based upon critical boundary shear stress values for each sediment class at a streamflow of 1,000 cubic feet per second for $(A)$ the expanded bridge, $(B)$ the widened channel, $(C)$ the stream channel dredged $50 \mathrm{ft}$ upstream from the bridge, and $(D)$ the stream channel dredged $200 \mathrm{ft}$ upstream from the bridge, Wymans Run study reach, Crawford County, Pa. 
of sediment filling the bridge opening is not a concern during peak flows of major events. A proposed bridge redesign could allow for higher velocities directly upstream from the bridge, perhaps decreasing the amount of sediment deposited directly upstream from the bridge opening. Results of the simulation for the hypothetical dredged channel show that less sediment was deposited at the bridge and as much as $200 \mathrm{ft}$ upstream for this scenario than for the other scenarios, indicating that sediment will likely continue to be deposited in these manmade sediment traps until the stream reaches its equilibrium slope. The most effective hypothetical channel geometry change for reducing flooding and over-topping of the left bank upstream from the bridge was the widening of the channel about 15 to $20 \mathrm{ft}$ on the left bank upstream from the bridge to match the hypothetical bridge expansion. However, the simulations show velocities will be reduced in the widened areas and sediment has a high potential of depositing.

\section{Acknowledgments}

The author would like to thank the residents who live near Wymans Run and Bob Rose for the pictures, stories, and history of the area. The author appreciates the work of Jeff Chaplin who provided photographs and other data for the study reach. The author is grateful to Charles Berenbrock for his technical assistance with MD_SWMS. Terry Kenney and Mark Roland of the USGS provided technical reviews of the manuscript.

\section{References Cited}

Arcement, G.J., Jr., and Schneider, V.R., 1984, Guide for selecting Manning's roughness coefficients for natural channels and flood plains: U.S. Geological Survey Water-Supply Paper 2339, 38 p.

Barton, G.J., McDonald, R.R., Nelson, J.M., and Dinehart, R.L., 2005, Simulation of flow and sediment mobility using a multidimensional flow model for the white sturgeon critical-habitat reach, Kootenai River near Bonners Ferry, Idaho: U.S. Geological Survey Scientific Investigations Report 2005-5230, 64 p.

Berenbrock, C., and Tranmer, A.W., 2008, Simulation of flow, sediment transport, and sediment mobility of the Lower Coeur d'Alene River, Idaho: U.S. Geological Survey Scientific Investigations Report 2008-5093, 164 p.

Chow, Ven Te., 1959, Open channel hydraulics: New York, McGraw-Hill, 680 p.
Geyer, A.R., and Wilshusen, J.P., 1982, Engineering characteristics of the rocks of Pennsylvania (2d ed.): Pennsylvania Geological Survey, 4th ser., Environmental Geology Report, $300 \mathrm{p}$.

Hjulström, Filip, 1939, Transportation of detritus by moving water: American Association of Petroleum Geologists, Symposium on Recent Marine Sediments, p. 5-31.

Karrok, 2009, Hjulstroms_diagram_sv.PNG, accessed May 5, 2010, at http://en.wikipedia.org/wiki/ File:Hjulstr\%C3\%B6ms_diagram_en.PNG.

Kenney, T.A., 2005, Initial-phase investigation of multidimensional streamflow simulations in the Colorado River, Moab Valley, Grand County, Utah, 2004: U.S. Geological Survey Scientific Investigations Report 2005-5022, 69 p.

McDonald, R.R., Nelson, J.M., and Bennett, J.P. [2005], Multi-dimensional surface-water modeling system user's guide: U.S. Geological Survey online documentation, accessed October 5, 2010, at http://wwwbrr.cr.usgs.gov/ projects/GEOMORPH_Lab/WebHelp_Pro/MD_SWMS.htm.

Nelson, J.M., Bennett, J.P., and Wiele, S.M., 2003, Flow and sediment-transport modeling, in Kondolf, G.M., and Piegay, H., eds., Tools in fluvial geomorphology: Oxford, England, John Wiley \& Sons, p. 539-576.

Rosgen, D.L., 1998, The reference reach field book: Pagosa Springs, Colo., DLR Wildland Hydrology, 209 p.

Sevon, W.D., comp., 2000, Physiographic provinces of Pennsylvania (4th ed.) [online]: Pennsylvania Geological Survey, 4th ser., Map 13, accessed July 28, 2004, at http://www.dcnr. state.pa.us/topogeo/maps/map13.pdf.

Sturm, T.W., 2001, Open channel hydraulics: New York, McGraw-Hill, 493 p.

Sundborg, A., 1956, The River Klarälven - A study of fluvial processes: Geografiska Annaler, v. 38, no. 2, p. 238-316.

U.S. Army Corps of Engineers, 2008, HEC-RAS River Analysis System User's Manual, v. 4.0

U.S. Army Corps of Engineers, 2009, HEC-GeoRAS GIS Tools for Support of HEC-RAS using ArcGIS User's Manual, v. 4.2.

Weather Underground, Inc., 2010, History for Meadville, PA-Thursday, June 5, 2008, accessed August 10, 2010, at http://www.wunderground. com/history/airport/KGKJ/2008/6/5/DailyHistory. $\mathrm{html}$ ?req_city $=$ Meadville\&req_state $=$ PA\&req statename $=$ Pennsylvania\%20).

Yaworski, M., Rector, D., Eckenrode, J., Jensen, E., and Grubb, R., 1979, Soil survey of Crawford County, Pennsylvania: U.S. Department of Agriculture Soil Conservation Service, 73 p., plus maps. 
For additional information, write to:

Director

U.S. Geological Survey

Pennsylvania Water Science Center

215 Limekiln Road

New Cumberland, PA 17070

or visit our Web site at:

http://pa.water.usgs.gov/ 


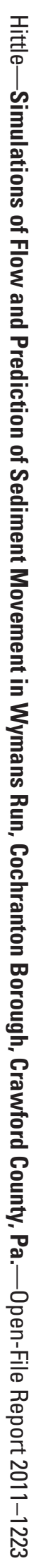

8 Printed on recycled paper 